\title{
The Importance of Physioxia in Mesenchymal Stem Cell Chondrogenesis and the Mechanisms Controlling Its Response
}

\author{
Girish Pattappa ${ }^{1, *(\mathbb{C}, \text { Brian Johnstone }}{ }^{2}$, Johannes Zellner ${ }^{1}$, Denitsa Docheva ${ }^{1}{ }^{\mathbb{C}}$ and \\ Peter Angele 1,3 \\ 1 Laboratory of Experimental Trauma Surgery, Department of Trauma Surgery, \\ University Hospital Regensburg, Franz Josef Strauss Allee 11, 93053 Regensburg, Germany; \\ johannes.zellner@ukr.de (J.Z.); denitsa.docheva@ukr.de (D.D.); peter.angele@ukr.de (P.A.) \\ 2 Department of Orthopaedics and Rehabilitation, Oregon Health \& Science University, \\ 3181 SW Sam Jackson Park Rd, Portland, OR 97239, USA; johnstob@ohsu.edu \\ 3 Sporthopaedicum Regensburg, Hildegard von Bingen Strasse 1, 93053 Regensburg, Germany \\ * Correspondence: girish.pattappa@ukr.de; Tel.: +49-941-943-1743
}

Received: 14 December 2018; Accepted: 21 January 2019; Published: 23 January 2019

check for updates

\begin{abstract}
Articular cartilage covers the surface of synovial joints and enables joint movement. However, it is susceptible to progressive degeneration with age that can be accelerated by either previous joint injury or meniscectomy. This degenerative disease is known as osteoarthritis (OA) and it greatly affects the adult population. Cell-based tissue engineering provides a possible solution for treating OA at its earliest stages, particularly focal cartilage lesions. A candidate cell type for treating these focal defects are Mesenchymal Stem Cells (MSCs). However, present methods for differentiating these cells towards the chondrogenic lineage lead to hypertrophic chondrocytes and bone formation in vivo. Environmental stimuli that can stabilise the articular chondrocyte phenotype without compromising tissue formation have been extensively investigated. One factor that has generated intensive investigation in MSC chondrogenesis is low oxygen tension or physioxia $(2-5 \%$ oxygen). In vivo articular cartilage resides at oxygen tensions between $1-4 \%$, and in vitro results suggest that these conditions are beneficial for MSC expansion and chondrogenesis, particularly in suppressing the cartilage hypertrophy. This review will summarise the current literature regarding the effects of physioxia on MSC chondrogenesis with an emphasis on the pathways that control tissue formation and cartilage hypertrophy.
\end{abstract}

Keywords: mesenchymal stem cells; chondrogenesis; hypoxia; cartilage; hypertrophy; hypoxia inducible factors; early osteoarthritis

\section{Introduction}

Articular cartilage is a tissue lining the surface of synovial joints that provides friction-free movement and facilitates load-bearing. Chondrocytes are the specialised cells within the tissue that create and maintain cartilage matrix that is primarily composed of aggrecan (a large proteoglycan) and collagen II. Chondrocyte orientation and matrix distribution within the tissue generates an anisotropic structure from the cartilage surface to the deep zone and outwards from the chondrocyte. These cartilage zones are described as the superficial, middle/transitional, deep and calcified zones; whilst the pericellular, territorial and interterritorial regions surround the chondrocyte. The differences in matrix distribution within these zones and regions contribute to cartilage biomechanics, enabling it to withstand high dynamic and compressive loads during joint loading [1,2]. 
However, articular cartilage is susceptible to progressive degeneration leading to changes in its structure and function. This degenerative disease is described as osteoarthritis (OA). Early observable events in OA include collagen fibrillation of the superficial layer that leads to loss of proteoglycans and other matrix molecules. Chondrocytes begin to proliferate and form clusters with increased matrix synthesis in response, whilst inflammatory cytokines stimulate the expression of matrix metalloproteinases (MMPs) and aggrecanases (ADAMTS) that facilitate cartilage degradation [3,4]. Eventually chondrocytes reduce their proliferative and anabolic response and the degeneration continues, whilst pain and changes in joint function become apparent and are clinical indicators for OA.

It has been noted that there is an increased risk of OA within the knee joint due to previous joint injury (e.g., anterior cruciate ligament (ACL) injury), excessive repetitive loading, joint dysplasia and meniscectomy. According to the German Cartilage Registry (Deutsche Gesellschaft für Orthopäedie und Unfallchirurgie (DGOU)) between October 2013-June 2014, 60\% of treated cartilage defects were degenerative, whilst a recent multi-centre study showed that of 400 patients, approximately $40 \%$ had chondral injuries resulting from degenerative conditions $[5,6]$. In classifying the forms of OA that can be treated, recent studies have described the term "early OA" [7-9]. This latter condition may be amenable to regenerative medicine or tissue engineering therapies. An example of cartilage tissue engineering is autologous chondrocyte implantation (ACI) that is currently being used to treat focal cartilage defects. However, a high failure and re-operation rate has been observed when treating focal degenerative lesions compared with post-trauma defects. One potential reason for their poor outcome is the surrounding inflammatory environment that impairs cell-based solutions. In particular, IL-1 $\beta$ has been shown to be a negative predictor for ACI treatment post-surgery $[5,10]$. Thus, a primary goal for clinicians and scientists is to develop regenerative options that can be used to treat both focal and diffuse early OA in this challenging environment.

Autologous articular chondrocytes are an established cell-based tissue engineering strategy for treatment of large "focal traumatic" or "focal early OA" chondral or osteochondral defects of the knee joint $[6,11,12]$. Mesenchymal stem cells (MSCs) can be isolated from a variety of sources including bone marrow, adipose (liposuction or intrapatellar fat pad) or synovium with minimal donor site morbidity [13-16] and have been shown to have chondrogenic potential, initially in vitro with the creation of pellets or micromasses and the addition of the stimulatory growth factor, transforming growth factor-beta (TGF- $\beta$ ) $[17,18]$. Scaffolds/biomaterials have been developed in which MSCs are seeded or encapsulated, and then chondrogenically differentiated to create clinically relevant chondrogenic implants that may be used to fill patient defects. However, in both pellets and scaffolds, markers of chondrocyte hypertrophy (collagen X, MMP13) have been detected and upon implantation in vivo, ectopic bone formation can occur [19]. Strategies to prevent hypertrophy and produce a stable articular chondrocyte phenotype with its defined extracellular matrix are the principle goals of in vitro cartilage tissue engineering.

Scientists have attempted to attain stable cartilage formation with environmental stimuli relevant to the in vivo situation, e.g., biomechanical stimulation, lower oxygen tension and/or addition of appropriate growth factors. The rationale for using low oxygen tension for cartilage tissue engineering is the oxygen level within articular cartilage that ranges from $2-5 \%$ oxygen (Figure 1) [20-24]. The use of growth factors (e.g., TGF- $\beta$ ), low oxygen tension and other stimuli for MSC chondrogenesis can also be used to cause the redifferentiation of articular chondrocytes in either pellets or hydrogels. Adding TGF- $\beta$ under physioxia upregulates chondrogenic gene (sex-determining region $Y$-box 9 (SOX9), collagen II alpha I (COL2A1) and aggrecan (ACAN)) expression and subsequent glycosaminoglycan (GAG) and collagen II accumulation, whilst downregulating the expression of catabolic genes (e.g., MMP9, MMP13), ADAMTS-4, ADAMTS-5) compared with cells in hyperoxic (atmospheric) conditions [25-32]. Similarly, OA chondrocytes cultured in the same low oxygen conditions also demonstrated an increase in GAG deposition and a reduction in the expression of MMPs, although they had higher collagen $X$ alpha I (COL10A1) and MMP13 expression and lower GAG deposition compared with healthy 
chondrocytes [30,31]. Additionally, low oxygen culture can also counter the inhibitory effects caused by the presence of inflammatory cytokines [29]. Thus, lowered oxygen tension could potentially help to induce a stable chondrogenic phenotype in MSC chondrogenesis, and many studies have been conducted to understand its effects on this process. The present review will summarise the literature and evaluate the effects of low oxygen tension or physioxia on MSC chondrogenesis, evaluating the outcomes of the various studies and the pathways that have been identified to be part of the cellular response to it. A Pubmed search was performed; the date of the last search was 31 October 2018. The keywords used for the gathering of relevant publications used the terms, "mesenchymal stem cells" and "hypoxia" or "chondrogenesis" or "chondrocytes". Publications since 2001 were evaluated for the purposes of this review.

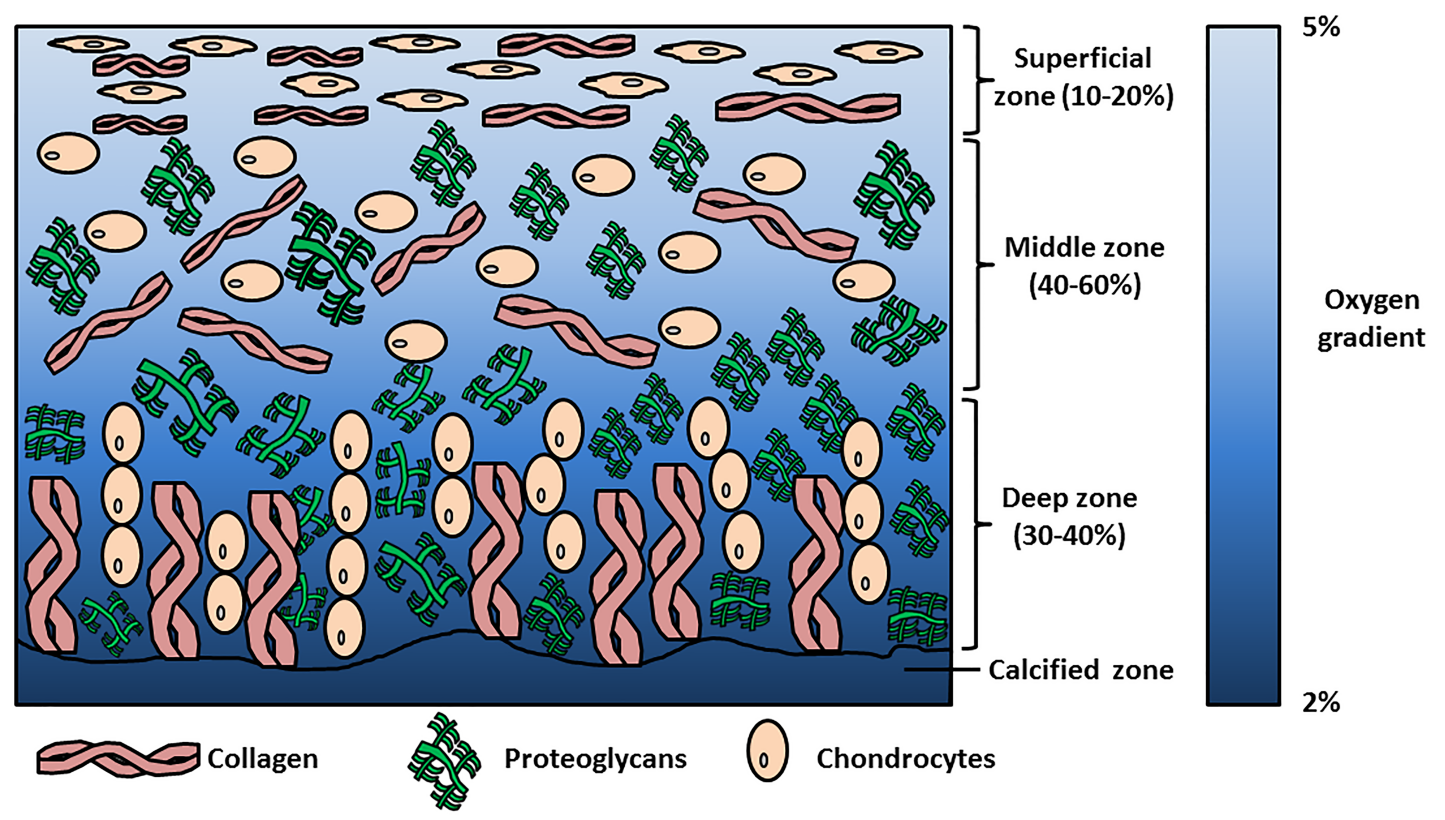

Figure 1. Schematic diagram describing the zones within articular cartilage and the changes in oxygen tension from the superficial zone to calcified zone.

\section{Physioxia and Cartilage}

In vivo physiological oxygen tension (physioxia) within human articular cartilage ranges from $2-5 \%$, whilst bone marrow physioxia has been measured at $7 \%$ oxygen (Figure 1 ) $[20,21,23,24]$. The atmospheric oxygen level ( $20 \%$ oxygen) at which most typical tissue culture incubators operate is actually non-physiological and represents hyperoxia [20,33].

In all of the studies summarised for this review, incubator oxygen tension (20\%; hyperoxia) is utilised as the 'control' for experiments done at physioxia even though the latter is closer to conditions found in vivo. An alternative method to mimic some of the effects of physioxia is through chemical induction, specifically on the pathway controlling the stability of hypoxia-inducible factor-1 alpha (HIF-1 $\alpha$ ) that has been found to be essential for chondrocyte survival and cartilage homeostasis (Figure 2) [34,35]. In chemically-induced physioxia, cobalt chloride is the most extensively studied compound. Under hyperoxia, HIF-1 $\alpha$ is hydroxylated by prolyl hydroxylases (PHDs) and factor inhibiting HIFs (FIH), resulting in its proteosomal degradation (Figure 2a). The process is catalysed by molecular oxygen, iron ions, ascorbic acid and 2-oxoglutarate [36-38]. Cobalt chloride competes with iron ions for the active site of PHD and prevents HIF-1 $\alpha$ hydroxylation, thereby stimulating a physioxic response in hyperoxic oxygen conditions. Other hydroxylase inhibitors have also been used to create a physioxia mimicking response, specifically dimethyloxalylglycine (a competitive inhibitor of PHDs and FIHs) and desferrioxamine (sequesters iron ions). Although this review primarily focusses on experiments 
that use altered incubator oxygen levels, studies utilising chemically-induced physioxic responses are discussed where appropriate $[36,39,40]$.
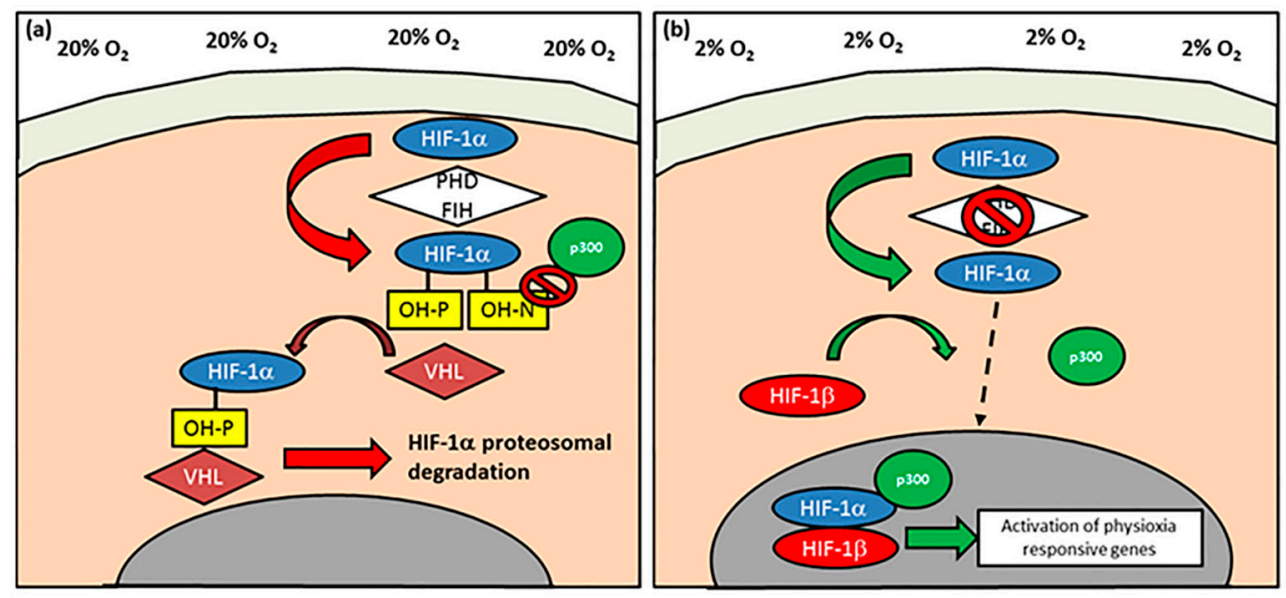

Figure 2. Schematic diagram describing the activation of hypoxia-inducible factor-1 alpha (HIF-1 $\alpha$ ). (a) Under normoxic/hyperoxic (20\% oxygen) conditions, HIF- $1 \alpha$ is hydroxylated by prolyl hydroxylases (PHDs) and factor inhibiting HIF (FIH) that enables HIF-1 $\alpha$ to undergo proteasomal degradation by von-Hippel-Lindau (VHL) E3 ubiquitin ligase complex. In contrast, PHD and FIH activity is inhibited under (b) hypoxia/physioxia ( $2 \%$ oxygen), thus leading to nuclear translocation of HIF-1 $\alpha$ that forms a complex with HIF-1 $\beta$ and co-factor p300, that results in upregulation of physioxia-responsive genes. Arrows describe the flow and stages involved in HIF-1 $\alpha$ behavior under (a) normoxia/hyperoxia and (b) hypoxia/physioxia (dotted arrow depicts HIF-1 $\alpha$ nuclear translocation).

\section{MSC Isolation and Expansion under Physioxia}

Investigators examining MSC proliferation under physioxia have demonstrated that the initial plating of human bone marrow produced greater colony-forming units-fibroblasts (CFU-Fs) upon culture in a low oxygen environment [41-44]. Furthermore, MSCs were able to proliferate at a shorter cell doubling time and have consequent increased cell numbers in physioxia [43-46]. This pattern has also been replicated in the majority of studies for chondrogenic cells from different tissue sources (adipose and synovium) and other species (porcine, ovine and murine) [43,45,47-53].

Long-term culture under lowered oxygen conditions caused MSCs to reach greater population doublings with reduced cellular senescence $[46,52,54,55]$. The latter phenomena has been postulated to be due to the underlying cellular ATP metabolism. Under hyperoxia, MSCs have an increased oxygen consumption, thereby having a greater ATP production via oxidative phosphorylation. In comparison, physioxic MSC cultures had greater lactate production and reduced oxygen consumption compared with hyperoxic MSC cultures, resulting in greater energy production via glycolysis $[54,56,57]$. The increased utilisation of oxidative phosphorylation under hyperoxia generated reactive oxygen species that can enhance cellular senescence [58]. Furthermore, telomeres that control cellular aging were found to be longer for physioxia-cultured MSCs [46]. These investigations demonstrate a clear advantage of physioxia for MSC expansion.

Studies have also demonstrated that stem cell markers that are typically associated with either embryonic or induced pluripotent stem cells (e.g., octamer-binding transcription 4 (OCT-4), stage-specific embryonic antigen (SSEA-1) are expressed on MSCs expanded in physioxia $[59,60]$. Consistent with this, physioxia-expanded MSCs can undergo osteogenesis and adipogenesis at later population doublings compared with those expanded in hyperoxia. However, there are also studies showing that osteogenesis is inhibited under physioxia and with physioxia expanded MSCs differentiated under hyperoxia, indicating that differences in oxygen tension can affect differentiation towards different musculoskeletal lineages $[48,54,59]$. The present review focusses on how physioxia affects 
MSC chondrogenesis in terms of the amount of matrix formation that occurs and the types of matrix molecules that are expressed. The influence on the latter is of particular interest, as hyperoxic in-vitro MSC chondrogenesis results in the expression of hypertrophic markers (e.g., collagen X, MMP13, alkaline phosphatase) that upon implantation in a nude mouse model result in ectopic bone formation in vivo [19].

\section{Physioxia and MSC Chondrogenesis}

\subsection{Chondrogenic Matrix Formation}

A summary of the outcomes for the effects of physioxia on MSC chondrogenic matrix formation are described in Tables 1 and 2. Mouse stromal cells in a pellet culture model demonstrated that physioxia (1\% oxygen) upregulated SOX9 gene expression and increased GAG deposition in the matrix [61]. Later studies were in agreement with the described investigation, whilst also observing an increase in pellet wet weight and an upregulation in COL2A1 and ACAN expression [46,62]. However, there are also studies that found a downregulation in matrix gene expression (SOX9, COL2A1, ACAN) and no effect on matrix formation [44,51,53,54,63-69]. One study using adipose-derived murine MSCs cultured under physioxia demonstrated a reduction in both GAG and collagen II matrix content compared to hyperoxia, in spite of larger pellet diameter [66]. It was assumed in these cases that oxygen gradients had formed under hyperoxia, whereby a physioxic region develops within the central regions of pellets or scaffolds that correspond to greater GAG and collagen II matrix deposition [63,70].

Donor variability has been shown to influence chondrogenic potential, especially in response to low oxygen culture. Anderson et al. [33] investigated the effect of physioxia on MSC preparations with different levels of chondrogenic potential. Their intrinsic chondrogenic capacity was based on the amount of GAG produced relative to that formed by articular chondrocytes formed under normal atmospheric conditions. It was demonstrated that in preparation with low GAG, there was enhanced chondrogenesis under physioxia, whilst high GAG producing MSC preparations did not get a significant enhancement from lower oxygen. Thus, the differences described in studies displaying no influence of physioxia on MSC chondrogenesis could be related to the donor variability in chondrogenic potential.

With this as a caveat, the majority of studies of MSC chondrogenesis either in pellet or scaffold cultures indicates an increase in chondrogenic genes (COL2A1 and $A C A N)$ and matrix formation under physioxia $[33,41-43,47,49,50,52,55,62,71,72,76-79,82,86-88,90,92,93,95,97]$. Furthermore, it has also been shown that physioxia is a more potent promoter of chondrogenesis than dynamic (compressive) loading with no synergistic effect upon combining the parameters $[78,98]$. 
Table 1. Summary of the key findings from publications examining the effect of physioxia on mesenchymal stem cell (MSC) chondrogenesis. Findings are relative to hyperoxia.

\begin{tabular}{|c|c|c|c|c|}
\hline Publication & Cell Source & Pellets or Scaffolds & Oxygen Tension & Results-Physioxia Response Relative to Hyperoxia \\
\hline Robins et al., 2005 [61] & $\begin{array}{l}\text { Mouse ST2 stromal } \\
\text { cells/C3H10T1/2 cells }\end{array}$ & Pellet & $1 \% \mathrm{O}_{2}$ & $\begin{array}{l}\text { Sex-determining region-box } 9 \text { (SOX9) expression is } \\
\text { upregulated and induces greater glycosaminoglycan (GAG) } \\
\text { deposition. Increased hypoxia-inducible factor- } 1 \text { alpha } \\
\text { (HIF-1 } \alpha \text { ) expression; no change in hypoxia-inducible factor-1 } \\
\text { beta (HIF-1 } \beta \text { ) expression }\end{array}$ \\
\hline Wang et al., 2005 [71] & Human adipose MSCs & $\begin{array}{l}\text { Scaffolds }\left(4 \times 10^{6} \text { cells } / \mathrm{mL}\right. \\
\quad \text { alginate beads })\end{array}$ & $5 \% \mathrm{O}_{2}$ & $\begin{array}{l}\text { Greater anaerobic respiration as measured by lactate } \\
\text { production both under expansion and chondrogenesis. } \\
\text { Increased GAG and collagen content }\end{array}$ \\
\hline Betre et al., 2006 [65] & Human adipose MSCs & $\begin{array}{l}\text { Scaffolds }\left(2 \times 10^{6} \text { cells/scaffold; }\right. \\
\text { elastin-like polypeptide } \\
\text { scaffold })\end{array}$ & $5 \% \mathrm{O}_{2}$ & $\begin{array}{l}\text { Upregulation in SOX9 and downregulation in collagen X } \\
\text { alpha } 1 \text { (COL10A1)—reduction in collagen II alpha I (COL2A1) } \\
\text { and aggrecan (ACAN). No difference in GAG or collagen } \\
\text { content between conditions }\end{array}$ \\
\hline Malladi et al., 2006 [66] & Murine inguinal fat pad MSCs & Pellets & $2 \% \mathrm{O}_{2}$ & $\begin{array}{l}\text { Reduced GAG/DNA and collagen content but larger } \\
\text { diameter pellets }\end{array}$ \\
\hline Khan et al., 2007 [72] & Infrapatellar fat pad MSCs & Pellet & $5 \% \mathrm{O}_{2}$ & $\begin{array}{l}\text { HIF1 } \alpha \text {, hypoxia inducible factor- } 2 \text { alpha }(\text { HIF } 2 \alpha) \text {, SOX5, SOX6, } \\
\text { SOX9, ACAN, COL } 2 A 1 \text { and COL10A1 increased expression. } \\
\text { HIF } 2 \alpha \text { had greater expression than HIF1 } \alpha \text {. Increased pellet } \\
\text { wet weight, GAG content and collagen II staining }\end{array}$ \\
\hline Malladi et al., 2007 [73] & $\begin{array}{l}\text { Murine adipose MSCs (HIF-1 } \alpha \\
\text { deleted mice) }\end{array}$ & Pellets & $2 \% \mathrm{O}_{2}$ & $\begin{array}{l}\text { HIF- } 1 \alpha \text { expressed by adipose MSCs. HIF-1 } \alpha \text { deleted MSCs } \\
\text { significantly decreased SOX9, ACAN and COL } 2 A 1 \\
\text { expression. HIF- } 1 \alpha \text { deleted micromasses had reduced GAG } \\
\text { and collagen II deposition }\end{array}$ \\
\hline Felka et al., 2009 [74] & Human bone marrow MSCs & Pellet & $2 \% \mathrm{O}_{2} ; 2 \mathrm{ng} / \mathrm{mL}$ IL-1 $\beta$ & $\begin{array}{c}\text { No difference in gene transcript levels. Larger pellets with } \\
\text { more matrix production. Physioxia increase chondrogenic } \\
\text { gene (SOX9, COL2A1, ACAN), pellet size and matrix } \\
\text { deposition with reduced expression in matrix } \\
\text { metalloproteinase ( } M M P 1 \text { and } M M P 13) \text { in IL-1 } \beta \text { inhibited } \\
\text { chondrogenesis }\end{array}$ \\
\hline Pilgaard et al., 2009 [63] & Adipose derived MSCs & Pellets & $15 \%, 10 \%, 5 \%, 1 \% \mathrm{O}_{2}$ & $\begin{array}{l}\text { SOX9, collagen I alpha I (COL1A1), COL2A1 and ACAN } \\
\text { upregulated at } 15 \% \text { oxygen and donwregulated under } \\
\text { physioxia. Reduction in COL10A1 expression. Increased } \\
\text { matrix staining and GAG synthesis at } 15 \% \\
\text { oxygen - reduced at lower oxygen tension. Increased matrix } \\
\text { synthesis in central regions of ambient cultures due to } \\
\text { oxygen gradients-central regions increase chondrogenesis } \\
\text { in 15\% oxygen culture }\end{array}$ \\
\hline
\end{tabular}


Table 1. Cont

\begin{tabular}{|c|c|c|c|c|}
\hline Publication & Cell Source & Pellets or Scaffolds & Oxygen Tension & Results-Physioxia Response Relative to Hyperoxia \\
\hline Baumgartner et al., 2010 [75] & Human bone marrow MSCs & $\begin{array}{l}\text { Scaffold }\left(20 \times 10^{6} \text { cells } / \mathrm{ml}\right. \\
\text { fibrin hydrogel })\end{array}$ & $3 \% \mathrm{O}_{2}$ & $\begin{array}{c}\text { Greater and earlier expression of COL2A1. Increased alcian } \\
\text { blue matrix staining }\end{array}$ \\
\hline Buckley et al., 2010 [76] & $\begin{array}{l}\text { Porcine infrapatellar fat pad } \\
\text { MSCs }\end{array}$ & $\begin{array}{l}\text { Scaffold }\left(15 \times 10^{6} \text { cells } / \mathrm{mL} \text { in }\right. \\
2 \% \text { agarose })\end{array}$ & $2 \% \mathrm{O}_{2}$ & $\begin{array}{l}\text { Greater GAG and collagen II content with increased } \\
\text { staining in core region. Superior mechanical properties }\end{array}$ \\
\hline Khan et al., 2010 [77] & Human bone marrow MSCs & Pellet & $5 \% \mathrm{O}_{2}$ & $\begin{array}{l}\text { Upregulated SOX6, COL2A1, ACAN, HIF1 } \alpha \text { and HIF2 } \alpha \\
\text { expression. Enhancement in pellet wet weight and GAG } \\
\text { content }\end{array}$ \\
\hline Merceron et al., 2010 [64] & Human adipose MSCs & Pellets & $5 \% \mathrm{O}_{2}$ & $\begin{array}{l}\text { COL2A1 expression enhanced and no difference in } A C A N \\
\text { expression. No difference in matrix deposition }\end{array}$ \\
\hline Meyer et al., 2010 [78] & Porcine bone marrow MSCs & $\begin{array}{c}\text { Scaffold }\left(15 \times 10^{6} \text { cells } / \mathrm{mL} \text { in }\right. \\
2 \% \text { agarose })\end{array}$ & $5 \% \mathrm{O}_{2}$ & $\begin{array}{l}\text { Greater GAG and collagen II content with increased staining } \\
\text { in central regions. Increase in dynamic and equilibrium } \\
\text { modulus. No synergistic effect with dynamic loading }\end{array}$ \\
\hline Li and Pei, 2011 [55] & $\begin{array}{l}\text { Human synovial fetal } \\
\text { fibroblasts }\end{array}$ & Pellets & $5 \% \mathrm{O}_{2}$ & $\begin{array}{l}\text { SOX9, ACAN and COL2A1 expression were upregulated. } \\
\text { Larger pellets with greater GAG and collagen II content }\end{array}$ \\
\hline Stoyanov et al., 2011 [79] & Human bone marrow MSCs & $\begin{array}{l}\text { Scaffolds }\left(4 \times 10^{6} \text { cells } / \mathrm{mL} \text { in }\right. \\
1.2 \%(w / v) \text { alginate beads })\end{array}$ & $2 \% \mathrm{O}_{2}$ & $\begin{array}{l}\text { Increase in SOX9 and COL10A1 expression. Greater GAG } \\
\text { and collagen II content. In the presence of GDF-5, increased } \\
A C A N \text { and COL2A1 expression compared to TGF- } \beta \text { groups } \\
\text { with reduced hypertrophy }\end{array}$ \\
\hline Gawlitta et al., 2012 [80] & Human bone marrow MSCs & Pellets & $5 \% \mathrm{O}_{2}$ & Reduced collagen $\mathrm{X}$ staining \\
\hline Meretoja et al., 2013 [67] & Bovine bone marrow MSCs & $\begin{array}{l}\text { Scaffolds (Poly }(\varepsilon \text {-caprolactone; } \\
\quad 4.5 \times 10^{6} \text { cells } / \mathrm{mL} \\
\text { monoculture or co-culture }(30 \% \\
\text { articular chondrocytes: } 70 \% \\
\text { MSCs) })\end{array}$ & $5 \% \mathrm{O}_{2}$ & $\begin{array}{l}\text { COL2A1 upregulated-further enhanced in co-culture. No } \\
\text { difference in GAG and collagen content in MSCs } \\
\text { monocultures-increased alkaline phosphastase (ALP) and } \\
\text { calcification under these conditions. MSC-Chondrocyte } \\
\text { co-cultures reduced MSC hypertrophy-chondrocytes } \\
\text { prevent this process }\end{array}$ \\
\hline Portron et al., 2013 [81] & $\begin{array}{l}\text { Rabbit and human adipose } \\
\text { MSCs }\end{array}$ & $\begin{array}{l}\text { Pellets; Scaffolds }\left(2 \times 10^{6}\right. \\
\text { cells } / \mathrm{mL} \text { (rabbit) or } 5 \times 10^{5} \\
\text { cells } / \mathrm{mL} \text { (human) in Si-HPMC) }\end{array}$ & $5 \% \mathrm{O}_{2}$ & $\begin{array}{c}\text { Upregulation in COL2A1 and ACAN in both cell and culture } \\
\text { types. Increased collagen II and GAG deposition. In vivo } \\
\text { implantation of physioxia preconditioned scaffolds had } \\
\text { higher O'Driscoll scores }\end{array}$ \\
\hline Leijten et al., 2014 [82] & Human bone marrow MSCs & Pellets & $2.5 \% \mathrm{O}_{2}$ & $\begin{array}{l}\text { SOX9, COL2A1 and ACAN gene expression upregulated } \\
\text { and COL10A1 and MMP13 gene expression downregulated. } \\
\text { Increased GAG staining for physioxia chondrogenesis. } \\
\text { Physioxic preconditioned chondrogenesis reduced } \\
\text { bone-like formation upon in vivo implantation }\end{array}$ \\
\hline Munir et al., 2014 [70] & Human adipose MSCs & $\begin{array}{l}\text { Pellets, Scaffolds }(8 \times 106 \\
\text { cells } / \text { mL in collagen type I/II } \\
\left.\text { scaffold-Chondroglide }{ }^{\mathrm{TM}}\right)\end{array}$ & $5 \% \mathrm{O}_{2}$ & $\begin{array}{c}\text { SOX9, COL1A1 and COL2A1 expression upregulated with } \\
\text { downregulated COL10A1. Increase in COL2A1/COL1A1 } \\
\text { and COL2A1/COL10A1 ratios. Increased matrix staining at } \\
\text { periphery and more core deposition in hyperoxic } \\
\text { pellets-same in scaffolds }\end{array}$ \\
\hline
\end{tabular}


Table 1. Cont.

\begin{tabular}{|c|c|c|c|c|}
\hline Publication & Cell Source & Pellets or Scaffolds & Oxygen Tension & Results-Physioxia Response Relative to Hyperoxia \\
\hline Zhu et al., 2014 [83] & Human bone marrow MSCs & $\begin{array}{l}\text { Scaffold }\left(20 \times 10^{6} \text { cells } / \mathrm{mL} ;\right. \\
\text { Hyaluronic acid hydrogel })\end{array}$ & $1 \% \mathrm{O}_{2}$ & $\begin{array}{l}\text { Reduced hypertophic marker (COL10A1, MMP13, ALP) } \\
\text { expression in low cross-linking hydrgoels. Increased GAG } \\
\text { content. High cross-linking density and hyaluronic acid } \\
\text { concentration increased expression of hypertrophy markers }\end{array}$ \\
\hline Portron et al., 2015 [84] & Human adipose MSCs & Pellets & $5 \% \mathrm{O}_{2}$ & $\begin{array}{c}\text { SOX9, ACAN and COL2A1 upregulation and } \\
\text { downregulation of COL10A1 and MMP13. No difference in } \\
\text { matrix staining }\end{array}$ \\
\hline Markway et al., 2016 [85] & Human bone marrow MSCs & Pellets & $\begin{array}{l}2 \% \mathrm{O}_{2} ; 7 \text { days } \pm \text { TNF- } \alpha(1 \\
\mathrm{ng} / \mathrm{mL}) \text { at } 2 \% \text { or } 20 \% \mathrm{O}_{2}\end{array}$ & $\begin{array}{l}\text { Reduction in TNF- } \alpha \text { generated loss in GAG content. } \\
\text { Reduced MMP2, MMP9 and MMP13; ADAMTS4/5 } \\
\text { expression. TNF- } \alpha \text { inhibited MSC chondrogenesis }\end{array}$ \\
\hline $\begin{array}{l}\text { Galeano-Garces et al., } 2017 \\
{[86]}\end{array}$ & Human adipose MSCs & PCL scaffolds and pellets & $2 \% \mathrm{O}_{2}$ & $\begin{array}{l}\text { HIF1A, SOX9, COL10A1 and indian hedgehog }(I H H) \text { were } \\
\text { significantly upregulated and COL1A1 downregulated in } \\
\text { pellet cultures. SOX9 and ACAN expression had increased } \\
\text { PCL scaffolds, whilst COL10A1 expression was higher in } \\
\text { hyperoxic cultures }\end{array}$ \\
\hline Legendre et al., 2017 [87] & Human bone marrow MSCs & $\begin{array}{l}\text { Collagen I/III sponges; TGF- } \beta \\
\text { and BMP2 chondrogenic } \\
\text { induction }\end{array}$ & $3 \% \mathrm{O}_{2}$ & $\begin{array}{l}\text { Significant upregulation in COL2A1 and an increase in } \\
\text { COL2A1/COL1A1 and COL2A1/COL10A1 ratio }\end{array}$ \\
\hline Gomez-Leduc et al., 2017 [69] & Human umbilical cord MSCs & $\begin{array}{l}\text { Collagen I/III sponges; TGF- } \beta \\
\text { and BMP2 chondrogenic } \\
\text { induction }\end{array}$ & $5 \% \mathrm{O}_{2}$ & $\begin{array}{l}\text { Lower expression of chondrogenic genes (SOX9, COL2A1 } \\
\text { and } A C A N \text { ). Downregulation in COL10A1 and MMP13 } \\
\text { expression, and reduced collagen X protein expression. } \\
\text { Change in oxygen tension from hyperoxia (Day 0-7) } \\
\text { followed by physioxia (Day 7-21) helped to stabilise } \\
\text { chondrogenic phenotype with reduction in hypertrophic } \\
\text { gene expression (COL10A1, MMP13) }\end{array}$ \\
\hline $\begin{array}{l}\text { Rodenas-Rochina et al., } 2017 \\
\text { [88] }\end{array}$ & Porcine bone marrow MSCs & $\begin{array}{l}\text { Polycaprolactone (PCL) } \\
\text { composite scaffolds and } \\
\text { PCL-hyaluronic acid coated } \\
\text { scaffolds }\end{array}$ & $5 \% \mathrm{O}_{2}$ & $\begin{array}{l}\text { Significant increase in GAG deposition-no difference in } \\
\text { collagen content. Greater collagen II staining }\end{array}$ \\
\hline Bae et al., 2018 [47] & Human synovium MSCs & Pellets & $5 \% \mathrm{O}_{2}$ & $\begin{array}{c}\text { Significant upregulation in } S O X 9, C O L 2 A 1 \text { and } A C A N \text {. } \\
\text { Downregulation in COL10A1. Increased GAG deposition } \\
\text { and collagen II protein expression with reduced collagen X } \\
\text { expression }\end{array}$ \\
\hline Desance et al., 2018 [68] & Equine umbilical cord MSCs & $\begin{array}{l}\text { Collagen I/III sponges; TGF- } \beta \\
\text { and BMP2 chondrogenic } \\
\text { induction }\end{array}$ & $3 \% \mathrm{O}_{2}$ & $\begin{array}{c}\text { No difference in chondrogenic gene (SOX9, COL2A1 and } \\
\text { ACAN) or hypertrophy gene (COL10A1, runt-related } \\
\text { transcription factor-2 (RUNX2)) expression. Hypertrophic } \\
\text { genes were expressed significantly lower than chondrogenic } \\
\text { genes }\end{array}$ \\
\hline
\end{tabular}


Table 2. Summary of key findings from publications examining the effect of physioxia preconditioning on MSC chondrogenesis. Findings are relative to hyperoxia.

\begin{tabular}{|c|c|c|c|c|}
\hline Publication & Cell Source & Pellets or Scaffolds & Oxygen Tension & Physioxia Chondrogenic Response Relative to Hyperoxia \\
\hline $\begin{array}{l}\text { Martin-Rendon et al., } 2007 \\
\text { [89] }\end{array}$ & Bone marrow MSCs & Pellets & $1.5 \% \mathrm{O}_{2}$ & $\begin{array}{l}\text { Upregulated and stabilised HIF- } 1 \alpha \text { expression. Increase in } \\
\text { SOX9 gene expression and pellet wet weight }\end{array}$ \\
\hline Xu et al., 2007 [49] & Murine adipose MSCs & Pellets & $2 \% \mathrm{O}_{2}$ & $\begin{array}{l}\text { COL2A1 upregulated; no difference in } S O X 9 \text { and } A C A N \\
\text { gene expression. Downregulation in MMPs }(M M P 2, M M P 3, \\
M M P 13) \text { and osteogenic genes }(R U N X 2, A L P) \text {. Physioxia } \\
\text { preconditioning increased proteoglycan deposition-no } \\
\text { influence of reoxygenation }\end{array}$ \\
\hline Krinner et al., 2009 [41] & Ovine bone marrow MSCs & Pellets & $5 \% \mathrm{O}_{2}$ & Enhancement in GAG and collagen II content \\
\hline Markway et al., 2010 [90] & Human bone marrow MSCs & Pellets & $2 \% \mathrm{O}_{2}$ & $\begin{array}{l}\text { ACAN, COL2A1 and COL10A1 upregulated. Increased } \\
\text { GAG content and larger pellets }\end{array}$ \\
\hline Ronziere et al., 2010 [91] & $\begin{array}{l}\text { Human bone marrow MSCs } \\
\text { and adipose MSCs (only } \\
\text { preconditioned) }\end{array}$ & Pellets & $2 \% \mathrm{O}_{2}$ & $\begin{array}{c}\text { No difference in COL2A1 and ACAN expression. Reduction } \\
\text { in hypertophic markers (COL10A1 and MMP13) in } \\
\text { physioxia preconditioned MSCs }\end{array}$ \\
\hline Muller et al., 2011 [62] & Human bone marrow MSCs & $\begin{array}{l}\text { Pellets, Scaffolds }\left(4 \times 10^{5} \text { cells }\right. \\
\quad \text { in } 10 \%(w / v) \text { gelatin })\end{array}$ & $4 \% \mathrm{O}_{2}$ & $\begin{array}{c}\text { Upregulation in } S O X 9, C O L 2 A 1, A C A N \text { and COL10A1 in } \\
\text { pellets and scaffolds. Larger pellets and increased GAG } \\
\text { content }\end{array}$ \\
\hline Weijers et al., 2011 [46] & Human adipose MSCs & Pellets & $1 \% \mathrm{O}_{2}$ & SOX9 and COL2A1 upregulated. Increase in GAG content \\
\hline Adesida et al., 2012 [42] & Human bone marrow MSCs & Pellets & $3 \% \mathrm{O}_{2}$ & $\begin{array}{l}\text { Upregulation in SOX9, COL2A1 and ACAN; } \\
\text { downregulation in COL10A1. Enhanced GAG content and } \\
\text { collagen II staining. Increase in transforming growth } \\
\text { factor-beta receptor one and two (TGFBR1 and TGFBR2) } \\
\text { and HIF-2 } \alpha \text { expression }\end{array}$ \\
\hline Duval et al., 2012 [92] & Human bone marrow MSCs & $\begin{array}{l}\text { Scaffolds }\left(5 \times 10^{6} \text { cells } / \mathrm{mL} \text { in }\right. \\
\text { alginate beads })\end{array}$ & $5 \% \mathrm{O}_{2}$ & $\begin{array}{l}\text { Increase in SOX5, SOX6, SOX9, ACAN and COL2A1 gene } \\
\text { expression and decrease in COL10A1, RUNX2 and ALP. } \\
\text { Greater GAG and collagen II content upon in vivo } \\
\text { implantation. Application of HIF-1 } \alpha \text { dominant negative } \\
\text { plasmid prevents anabolic response }\end{array}$ \\
\hline Sheehy et al., 2012 [45] & Porcine bone marrow MSCs & $\begin{array}{l}\text { Pellets; Scaffold }\left(15 \times 10^{6}\right. \\
\text { cells } / \mathrm{mL}, 2 \% \text { agaose })\end{array}$ & $5 \% \mathrm{O}_{2}$ & $\begin{array}{c}\text { Increase in GAG and collagen in both pellets and scaffolds } \\
\text { (develops a pericellular matrix). Reduction in } A L P ; \\
\text { suppression in hypertrophy }\end{array}$ \\
\hline Lee et al., 2013 [93] & Human bone marrow MSCs & Pellets & $2 \% \mathrm{O}_{2}$ & $\begin{array}{c}\text { SOX9, COL2A1 and ACAN expression upregulated and } \\
\text { COL10A1 and RUNX2 downregulated. Matrix staining for } \\
\text { GAG, collagen II and collagen X support findings. Reduced } \\
\text { staining for apoptotic markers (Caspase }-3 \text { and }-8 \text { ). Akt and } \\
\text { downstream targets, FOXO1 and FOXO3, were } \\
\text { phosphorylated-Inhibition of pathway, increased } \\
\text { hypertrophy (COL10A1 and RUNX2) and reduced response. } \\
\text { No effect on hyperoxic chondrogenesis }\end{array}$ \\
\hline
\end{tabular}


Table 2. Cont.

\begin{tabular}{|c|c|c|c|c|}
\hline Publication & Cell Source & Pellets or Scaffolds & Oxygen Tension & Physioxia Chondrogenic Response Relative to Hyperoxia \\
\hline $\begin{array}{l}\text { O'HEireamhoin et al., } 2013 \\
\text { [49] }\end{array}$ & $\begin{array}{l}\text { Human infrapatellar fat pad } \\
\text { MSCs }\end{array}$ & $\begin{array}{l}\text { Pellets, scaffolds }\left(20 \times 10^{6}\right. \\
\text { cells } / \mathrm{mL} \text { in } 2 \% \text { agarose or } \\
\text { fibrin) }\end{array}$ & $5 \% \mathrm{O}_{2}$ & $\begin{array}{c}\text { Increase in GAG and collagen II content in pellets. Only GAG } \\
\text { deposition increased within scaffolds-reduced collagen X } \\
\text { staining }\end{array}$ \\
\hline Pattappa et al., 2013 [54] & Human bone marrow MSCs & Pellets & $5 \%$ or $2 \% \mathrm{O}_{2}$ & No difference in GAG content \\
\hline Ranera et al., 2013 [94] & Equine bone marrow MSCs & Pellets & $5 \% \mathrm{O}_{2}$ & $\begin{array}{c}\text { SOX9, COL2A1, ACAN, cartilage oligomeric matrix protein } \\
(C O M P) \text { gene expression upregulated. Physioxia } \\
\text { preconditioned cells enhanced GAG content. HIF- } 1 \alpha \\
\text { expression increased with time }\end{array}$ \\
\hline Boyette et al., 2014 [44] & Ovine bone marrow MSCs & Pellets & $5 \% \mathrm{O}_{2}$ & $\begin{array}{l}\text { Enhanced chondrogenesis in physioxia differentiated cells but } \\
\text { inhibited differentiation for physioxia preconditioned cells }\end{array}$ \\
\hline Kalpakci et al., 2014 [50] & Dermis isolated MSCs & Pellets & $5 \% \mathrm{O}_{2}$ & $\begin{array}{l}\text { Increased GAG and collagen content in physioxia } \\
\text { preconditioned MSCs; collagen II content was greater under } \\
\text { hyperoxia }\end{array}$ \\
\hline Bornes et al., 2015 [43] & Ovine bone marrow MSCs & $\begin{array}{l}\text { Scaffolds }\left(1 \times 10^{7} \text { cells } / \mathrm{cm}^{2} \text { on }\right. \\
\text { either collagen type I and } \\
\text { esterified hyaluronic acid } \\
\text { scaffolds })\end{array}$ & $3 \% \mathrm{O}_{2}$ & $\begin{array}{c}\text { Upregulated ACAN and COL2A1 gene expression and } \\
\text { downregulation in COL10A1. Enhanced GAG and collagen II } \\
\text { content in both scaffold types }\end{array}$ \\
\hline Anderson et al., 2016 [33] & Human bone marrow MSCs & Pellets & $2 \% \mathrm{O}_{2}$ & $\begin{array}{l}\text { COL2A1 and ACAN upregulated whilst COL10A1 and } \\
\text { MMP13 downregulated depending upon chondrogenic } \\
\text { capacity. Enhanced GAG production. MSCs with high } \\
\text { chondrogenic capacity stained for collagen X inspite of } \\
\text { physioxic culture }\end{array}$ \\
\hline Henrionnet et al., 2016 [95] & Human bone marrow MSCs & Alginate beads & $5 \% \mathrm{O}_{2}$ & $\begin{array}{l}\text { Upregulated } S O X 9, C O L 2 A 1, A C A N \text { and } C O M P \text {, } \\
\text { downregulated } R U N X 2 \text { and } A L P \text { expression. No change in } \\
\text { COL10A1 expression. Sequential hyperoxia then physioxia } \\
\text { increased COL2A1 and } A C A N \text { expression with reduction in } \\
\text { COL10A1 expression. No calcification }\end{array}$ \\
\hline Hudson et al., 2016 [96] & Human MSCs & Collagen-alginate scaffold & $5 \% \mathrm{O}_{2}$ & Greater GAG content and mechanical properties \\
\hline Ohara et al., 2016 [53] & Human synovial derived MSCs & Pellets & $5 \% \mathrm{O}_{2}$ & No difference in pellet wet weight or matrix staining \\
\hline Yasui et al., 2016 [52] & Synovium MSCs & $\begin{array}{l}\text { Scaffolds (Sheet-like construct, } \\
\qquad 4 \times 10^{5} \text { cells } / \mathrm{cm}^{2} \text { ) }\end{array}$ & $5 \% \mathrm{O}_{2}$ & $\begin{array}{c}\text { Increase in } S O X 9, A C A N \text { and } C O L 2 A 1 \text { expression. Increased } \\
\text { GAG and collagen II content }\end{array}$ \\
\hline Bornes et al., 2018 [51] & Ovine bone marrow MSCs & HYAFF scaffolds & $3 \% \mathrm{O}_{2}$ & $\begin{array}{l}\text { No difference in COL2A1 and ACAN gene expression but } \\
\text { significant increase in GAG content after } 14 \text { days culture. } \\
\text { Significant downregulation in COL10A1 with concomitant } \\
\text { increase in COL2A1/COL10A1 ratio at day } 4 \text { and } 14 \text {. No } \\
\text { difference in cartilaginous tissue formation in preconditioned } \\
\text { chondrogenic MSCs upon in vivo implantation }\end{array}$ \\
\hline Lee et al., 2018 [97] & Human bone marrow MSCs & Pellets & $1 \% \mathrm{O}_{2}$ & $\begin{array}{l}\text { Upregulation in SOX9, COL2A1 and ACAN expression. } \\
\text { Increase in GAG deposition }\end{array}$ \\
\hline
\end{tabular}




\subsection{MSC Hypertrophy}

The effect of physioxia on chondrogenic hypertrophy has been a focus of many studies. A downregulation in hypertrophic (COL10A1) gene expression has been measured in the majority of studies $[33,42,43,47,51,63,65,69,70,80,82-84,87,92,93,95]$, although there is some recorded upregulation $[62,67,72]$ in this hypertophic marker. It has also been shown that the timing of physioxic culture influences this process. Culture under physioxia after an initial 2 weeks of hyperoxic culture significantly reduced the expression of hypertrophic genes and increased that of hypertrophy antagonists, Gremlin-1 (GREM1), Frizzled-related protein (FRZB) and Dickkopf WNT (DKK1). These antagonists were reduced and hypertrophic genes were upregulated upon hyperoxic culture [82].

As previously discussed, Anderson et al. [33] demonstrated the importance of low GAG and high GAG MSC preparations on chondrogenic matrix production. Subsequent analysis of hypertrophy genes indicated that despite a downregulation of COL10A1 in both MSC preparations, only high GAG MSC donors expressed a significant difference relative to hyperoxic conditions. However, collagen $X$ staining was observed in physioxia-treated pellets independent of whether they were high or low GAG MSCs. This also demonstrates differences in gene expression and protein data with respect to hypertrophy, and this has been shown in a few studies [33,42,82,99]. Thus, physioxia suppresses collagen $\mathrm{X}$ expression but does not completely inhibit its production.

A few studies have shown that physioxia also downregulates collagenases (MMP13) and aggrecanases (ADAMTS-4 and ADAMTS-5) involved in cartilage hypertrophy. Examination of osteogenic gene expression (runt-related transcription factor-2 (RUNX2), osteopontin and osteonectin) and calcium deposition within the cartilaginous matrix was also found to be inhibited under physioxia $[45,83,91]$. In this instance, inhibited osteogenesis may be related to an underlying metabolism that favours a glycolytic metabolism, which is a critical component for sustaining an articular chondrocyte phenotype and thus, may also operate during MSC chondrogenic differentiation [57,59,71]. A microarray analysis showed an upregulation in glycolysis pathway-associated enzymes under physioxia, indicating its importance in developing a stable chondrocyte phenotype [82].

\subsection{MSC Preconditioning and In Vivo Implantation}

MSC that have been pre-expanded or preconditioned under physioxia prior to subsequent chondrogenesis under the same conditions demonstrated an enhancement in matrix deposition and a reduction in collagen $\mathrm{X}$ and other hypertrophy markers compared with non-preconditioned chondrogenic MSCs differentiated under physioxia (summarised in Table 2) [41-43,45,46,48,49,52,62,89-91,93-95,97]. Martin-Rendon et al. (2007) showed that preconditioned MSCs had higher SOX9 gene expression and subsequent pellet wet weight [89]. Physioxic preconditioned MSCs have demonstrated an increase in gene expression and cartilage matrix formation, even when differentiated under hyperoxia, when compared with non-preconditioned MSCs [42,43]. Examination of physioxia isolated MSCs has been shown to have a significantly reduced expression in CD90 or Thy-1 expression under these conditions [42]. Articular chondrocytes have been shown to not express CD90 in vivo but it is expressed during in vitro culture, concomitant with a loss of chondrogenic potential [100]. Potentially, a pre-selection process occurs under physioxia, whereby a chondroprogenitor population is isolated. It might be possible to use CD90 or other cell surface markers to evaluate whether physioxia can select for MSCs that have a high chondrogenic potential.

Subsequent implantation of physioxia-conditioned chondrogenic MSCs in vivo has been shown to increase cartilage matrix formation (collagen II and GAG) compared with implanted hyperoxic-conditioned MSCs. Furthermore, physioxia-preconditioned MSCs demonstrated reduced bone-like formation in both nude mouse and rabbit models, unlike previous investigations using hyperoxic MSCs in nude mouse models [81,82,92]. However, in larger animal models, despite an increase in in vitro chondrogenic gene expression and matrix formation, subsequent in vivo implantation provided no significant advantage relative to hyperoxic MSCs [51]. The sustained low oxygen environment in vivo could eliminate the difference between physioxic and hyperoxic 
preconditioning that is seen in short-term in vitro cultures. Further studies are required to understand whether physioxic preconditioned MSCs or chondrogenic implants are beneficial for in vivo chondrogenesis, specifically in larger animal models.

\subsection{Physioxia Prevents Cytokine Inhibited Chondrogenesis}

To mimic the OA environment and evaluate the performance of MSC chondrogenic implants for the treatment of focal defects, inflammatory cytokines have been used. IL- $1 \beta$ and TNF- $\alpha$ have previously been demonstrated to inhibit MSC chondrogenesis under hyperoxia [74,85]. An investigation showed that the reduction in matrix formation in the presence of IL-1 $\beta$ was suppressed by physioxic culture [74]. In particular, the matrix degradative enzymes (MMP1, MMP3 and MMP13) induced by IL-1 $\beta$ presence were reduced under physioxia. A recently published study reported similar results, but it was noted that physioxia does not completely restore chondrogenesis to control levels in the presence of IL-1 $\beta$, and only low GAG MSC donors or physioxia responders displayed a significant increase in chondrogenic gene expression and cartilage matrix formation [99].

A potential reason for the restoration of the chondrogenic phenotype in the presence of IL- $1 \beta$ may be related to the upregulation in TGF- $\beta$ receptors I and II under physioxia chondrogenesis. In this instance, chondrocytes in the presence of IL-1 $\beta$ have been shown to impair matrix production through downregulating TGF- $\beta$ receptor II expression, whilst upregulating the NF- $\mathrm{KB}$ pathway [101-103]. This hypothesis was supported by a recent investigation, whereby there was an upregulation in TGF- $\beta$ receptor I and II expression in physioxia MSC chondrogenesis in the presence of IL- $1 \beta$ compared to a downregulation in these receptors in the corresponding hyperoxic condition [99].

As well as the documented increase in inflammatory cytokines, the process of OA has also been found to increase in oxygen tension within the joint [22]. Reoxygenation of physioxia MSCs mimics the changes in oxygen tension during OA. In vitro experiments demonstrated that reoxygenating MSC chondrogenic pellets in the presence of TNF- $\alpha$ showed an increase in aggrecanolysis with subsequent upregulation in ADAMTS4/5 and MMP expression [85]. Thus, physioxia helps to suppress inflammatory cytokine-inhibited MSC chondrogenesis via suppression of matrix degradative enzymes and restoration of TGF- $\beta$ receptors [99].

\section{Physioxia Mechanisms in MSC Chondrogenesis}

\subsection{Hypoxia Inducible Factors (HIF): HIF-1 $\alpha$}

Investigations of the mechanism controlling the chondrogenic response under physioxia have noted the importance of the hypoxia-inducible factor (HIF) genes. The HIF genes belong to the basic helix-loop-helix (bHLH)-Per-Ant-Sim (PAS) family of transcription factors [104-106]. There are three HIF genes, HIF-1, HIF-2 and HIF-3, which consist of two sub-units, an unstable oxygen-sensitive alpha sub-unit and a stable oxygen-insensitive beta sub-unit. The most studied is HIF-1 $\alpha$, which has been described to be essential in cartilage development [34,35]. Under hyperoxic conditions, HIF-1 $\alpha$ is hydroxylated by PHDs and this exposes 4-hydroxyproline residues on the molecules. These exposed residues are recognised by the von-Hippel-Lindau (VHL) E3 ubiquitin ligase complex, resulting in its proteasomal degradation. Alongside this process, FIH hydroxylates the asparagine residue on HIF- $1 \alpha$, thereby preventing its binding to the co-factor p300 (Figure 2a). In contrast, physioxia inhibits PHD and FIH hydroxylation, enabling HIF- $1 \alpha$ to translocate the nucleus and dimerize with HIF-1 $\beta$ (Figure 2b).

HIF- $1 \alpha$ activation upregulates the expression of physioxia-sensitive genes that include the cartilage transcription factors, SOX5, SOX6 and SOX9, plus matrix genes, COL2A1 and ACAN [72,73,77,92]. It has been shown that HIF-1 $\alpha$ interacts with SOX9 to upregulate COL2A1 and ACAN, whilst downregulating COL10A1 expression under physioxia [92]. However, using either cadmium chloride (chemical physioxia inhibitor) or HIF-1 $\alpha$ dominant negative plasmid on physioxia-cultured chondrogenic MSCs reduced SOX9, COL2A1 and ACAN expression, whilst COL10A1 expression 
was increased. The importance of HIF-1 $\alpha$ was further supported in a recent study, whereby chondrogenically differentiating HIF-1 $\alpha$ deleted murine adipose MSCs under physioxia and developed micromasses with reduced GAG and collagen II content compared to controls [73]. Furthermore, an analysis of different HIF-1 $\alpha$ hydroxylase inhibitors that chemically-induced physioxia effects under hyperoxia via HIF-1 $\alpha$ stabilisation was also performed [36]. Dimethyloxalylglycine (DMOG), a competitive inhibitor of PHD and FIH, was found to induce the most stable articular chondrocyte phenotype in MSC chondrogenesis compared with other forms of chemically-induced physioxia. Application of the HIF- $1 \alpha /-\beta$ complex inhibitor, acriflavine, on DMOG induced MSC chondrogenesis and downregulated SOX9 and COL2A1 gene expression, whilst upregulating COL10A1 and increasing hypertrophic chondrogenesis. This indicates that stable HIF-1 $\alpha$ is an important component involved in the physioxic chondrogenic response (Figure 3a).

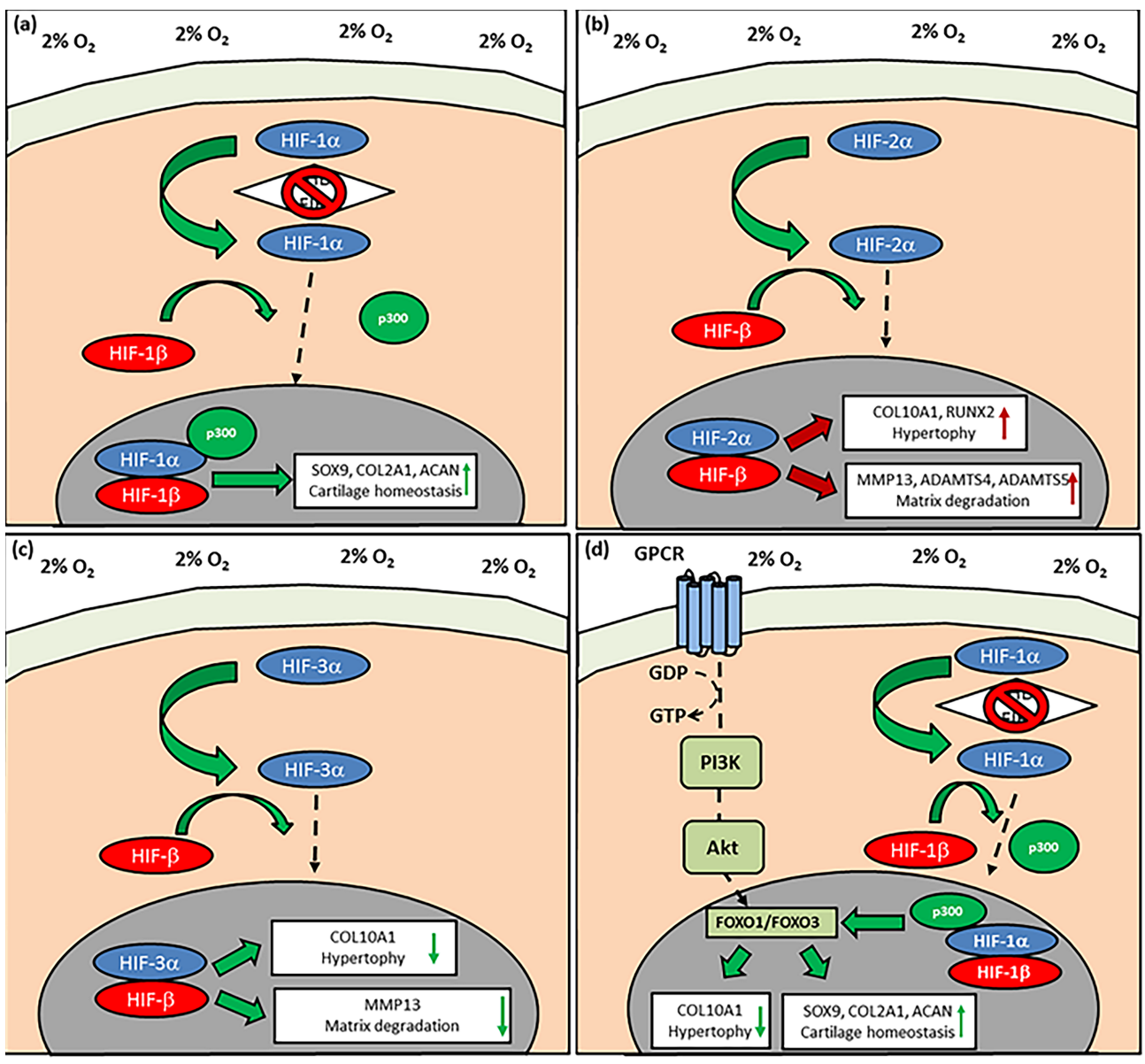

Figure 3. The pathways controlling the response of physioxia MSC chondrogenesis. (a) HIF-1 $\alpha$ upon translocation into the nucleus and dimerization with $H I F-1 \beta$ leads to upregulation of chondrogenic matrix gene expression, whereas (b) HIF- $2 \alpha$ nuclear translocation and dimerization results in an upregulation in cartilage hypertrophic and matrix degradation enzyme gene expression. The effect of HIF- $2 \alpha$ can be countered by the upregulation of (c) HIF- $3 \alpha$, which upon activation, counters the upregulation in hypertrophic and matrix degradation gene expression. (d) The PI3K/Akt/FOXO pathway is activated under physioxia in response to HIF-1 $\alpha$ translocation and helps to maintain chondrocyte phenotype via reduction in chondrocyte hypertrophy markers (green arrow direction symbolizes positive upregulation or downregulation in chondrogenic or hypertrophic genes; red arrow direction symbolizes negative upregulation in hypertrophic and matrix degradative enzyme gene expression; dotted arrow depicts HIF- $1 \alpha$, HIF- $2 \alpha$ or HIF- $3 \alpha$ nuclear translocation).

Additionally, stable HIF-1 $\alpha$ expression has been demonstrated to induce genes associated with the glycolysis pathway both in articular chondrocytes and chondrogenic MSCs [57,71,82]. Articular 
chondrocytes have highly glycolytic metabolism due to their in vivo environment and they undergo cellular senescence upon hyperoxic culture due to the production of reactive oxygen species $[54,55,58]$. Chondrogenic MSCs have also shown the same cellular metabolism during differentiation, and physioxia helps sustain this glycolytic metabolism. Thus, activation and stabilisation of the HIF- $1 \alpha / H I F-1 \beta$ complex could be a factor in achieving a stable articular chondrocyte phenotype.

\subsection{HIF-2a}

HIF- $2 \alpha$ or EPAS-1 has been investigated in chondrocytes and MSCs with regards to its expression both in physioxia and OA cartilage [107-110]. Coimbra et al. [109] demonstrated that HIF-2 $\alpha$ was expressed on an mRNA level in both normal and osteoarthritic chondrocytes under hyperoxic conditions. This result has been replicated in a recent investigation, whereby HIF- $1 \alpha$ and HIF- $2 \alpha$ were expressed under hyperoxic and physioxic conditions in both healthy and OA chondrocytes [31].

HIF- $2 \alpha$ expression in hypertrophic and osteoarthritic chondrocytes has been a major focus area with contrary results regarding its function in these particular processes. In embryonic mouse tibial cartilage, HIF-2 $\alpha$ expression was located in the hypertrophic zone alongside chondrocytes expressing hypertrophic markers, COL10A1 and MMP13 [110]. HIF-2 $\alpha$ overexpression in a mouse chondrocyte cell line (ATDC5) resulted in an upregulation of hypertrophic, OA-associated (e.g., COL10A1, MMP13 and vascular endothelial growth factor (VEGF)) and osteogenic (e.g., RUNX2, osteopontin) genes. Furthermore, an analysis of healthy and OA cartilage from human donors indicated greater HIF-2 $\alpha$ expression with increasing OA grade. The results were also supported by an independent study (Figure 3b) [107].

These studies also included mouse models to understand whether these in vitro effects were observed in vivo $[107,110]$. In one study, transgenic HIF- $2 \alpha$ overexpressing mice using promoter and enhancer regions of mouse COL2A1 gene were developed to understand the in vivo response [107]. With age, there was increased cartilage degradation with the concomitant expression of MMPs, aggrecanses and downstream catabolic targets, nitric oxide synthase (NOS2) and prosteoglandin-endoperoxide synthase-2 (PTGS2). Saito et al. (2010) [110] generated heterozygous HIF- $2 \alpha$ knockout $\left(H I F-2 \alpha^{+/-}\right)$mice that had a larger hypertrophic zone with a reduced bone area compared to wild type mice, indicating that HIF-2 $\alpha$ insufficiency prevents chondrocyte hypertrophy and subsequent matrix degradation and vascularization. Furthermore, use of either collagenase injection or a displaced medial meniscus (DMM) model to induce osteoarthritis in these heterozygous mice demonstrated no cartilage degeneration and a suppression of MMP and aggrecanase expression and downstream catabolic targets, NOS2 and PTGS2 [107]. Thus, these models indicate that HIF-2 $\alpha$ expression results in cartilage destruction, whilst its inhibition prevents $\mathrm{OA}$ and endochondral bone development. Studies investigating the effects of inflammatory cytokines (IL-1 $\beta$ and IL-6) on mouse articular chondrocytes showed that an increase in HIF- $2 \alpha$ expression induced cartilage destruction via the downstream activation of the NF-KB pathway, a well-described OA mechanism $[107,111]$.

However, these early publications have been questioned by recent investigations that replicated the conditional HIF-2 $\alpha$ knockout mouse model and demonstrated that it only induced a delay in endochondral ossification with no change in COL10A1 expression and no correlation in human subjects between HIF-2 $\alpha$ expression and idiopathic OA [112-114]. Furthermore, in-vitro physioxic culture of human articular chondrocytes or chondrogenic MSCs has been shown to upregulate HIF-2 $\alpha$ and subsequently promotes cartilage matrix gene expression and formation $[26,42,72]$. A commentary suggested that differences in mouse and human cartilage, particularly with respect to cartilage loading and thickness, mean that HIF- $2 \alpha$ in humans and larger animals has evolved into an anabolic gene rather than a catabolic gene described in mouse studies [114]. Additionally, the in vitro experiments examining HIF- $2 \alpha$ overexpression were conducted under hyperoxia; thus, it is not known how this would be influenced under physioxia. Therefore, the function of HIF- $2 \alpha$ remains elusive and further studies are required in both chondrocytes and chondrogenic MSCs under physioxia to understand its contribution to chondrogenesis and cartilage homeostasis. 


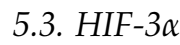

The third isoform, HIF-3 $\alpha$, has only recently been investigated in chondrogenesis [115-117]. Articular chondrocytes upon redifferentiation expressed HIF-3 $\alpha$ micromass pellet cultures with greater expression under physioxia, although it had a lower gene expression level compared to HIF-1 $\alpha$ and HIF- $2 \alpha$ under the same conditions [115]. A reason for the differences in transcript levels may be related to only a small number of chondrocytes expressing the gene. However, the fact that it was highly expressed in physioxic cultures and corresponded to the upregulation in cartilage matrix genes during redifferentiation suggested that it was contributory to the chondrocyte phenotype. Furthermore, there is evidence that upregulated HIF-3 $\alpha$ expression under physioxia inhibits COL10A1 and MMP13 expression, whilst knockdown of this gene upregulates these OA markers under the same conditions in a Ewing sarcoma cell line [116].

A recent study investigated HIF-3 $\alpha$ expression in articular chondrocytes and chondrogenic MSCs under physioxia and hyperoxia to understand whether its expression was associated with preventing hypertrophy [117]. Chondrogenic MSCs under physioxia and hyperoxia showed a low HIF-3 $\alpha$ expression, whilst there was higher expression for COL10A1 and MMP13. In contrast, redifferentiated articular chondrocytes had a higher HIF-3 $\alpha$ expression and downregulation in COL10A1 and MMP13, independent of the oxygen condition. Furthermore, OA chondrocytes were found to have a downregulation in HIF-3 $\alpha$ expression compared with healthy articular chondrocytes. Analysis of human embryonic growth plate cartilage demonstrated that HIF-3 $\alpha$ expression was greatest in the precursor chondrocyte region, whilst hypertrophic chondrocytes exhibited minimal HIF- $3 \alpha$ expression but had maximal expression for COL10A1 and MMP13 compared with other regions within the growth plate [117]. These findings indicate that HIF-3 $\alpha$ is a regulator of chondrocyte hypertrophy, whereby its expression prevents hypertrophic gene expression and is diminished in cells with an upregulation in hypertrophic genes such as OA chondrocytes and chondrogenically differentiated MSCs (Figure 3c).

Investigations into HIF-3 $\alpha$ expression, specifically in the previously described high and low GAG MSC donors could lead to an understanding of how HIF-3 $\alpha$ can control MSC chondrogenic hypertrophy especially under physioxia. Furthermore, there is evidence that HIF-3 $\alpha$ expression inhibits downstream targets of HIF-1 $\alpha$ and HIF-2 $\alpha$. Based on investigations on articular chondrocytes and the described literature, it has been postulated that HIF-3 $\alpha$ stabilisation inhibits the catabolic effects exerted by HIF-2 $\alpha$ under physioxia [117]. The inter-relationship between these HIF genes in physioxia MSC chondrogenesis requires further investigation.

\subsection{PI3K/Akt/FOXO Pathway}

A process that has been gradually investigated in OA research is the process of apoptosis, as this contributes to the initiation of the disease via chondrocyte cell death. Furthermore, the classical process of endochondral ossification has been thought to involve the apoptosis of hypertrophic chondrocytes that initially express COL10A1 and RUNX2, although there is now an evolving paradigm that is contrary to this process and involves the transdifferentation of chondrocytes into osteoblasts [118-120]. Thus, anti-apoptotic pathways are a potential mechanism for preventing chondrogenic MSC hypertrophy.

One relevant mechanistic pathway that has been investigated in MSC chondrogenesis is the PI3K/Akt pathway [93,121-124]. Transgenic mice containing an Akt fusion protein that enables constitutive Akt activation in articular cartilage resulted in highest Akt phosphorylation in resting and proliferative chondrocytes but reduced expression in hypertrophic chondrocytes [121]. An embryonic limb explant model using limbs from wild type and transgenic Akt mice was used to understand the significance of the PI3K/Akt pathway with respect to cartilage development. Following 5 days of culture, Akt activation increased the proliferative and reduced the hypertrophic zone within the limb. Use of a PI3K inhibitor (LY294002) on wild-type limbs only, reversed this effect and increased the hypertrophic zone within cartilage. These explant results were replicated in vitro, using human 
synovial stromal cells (hSSCs) in a pellet culture model. Lentivirally transduced hSSCs that expressed Akt gene via application of 4-hydroxytamoxifen, had increased pellet size and GAG deposition that corresponded with elevated SOX9, COL2A1 and ACAN expression. Gene expression of COL10A1 and RUNX2 was downregulated under these conditions. However, inhibition of PI3K using LY294002 in hSSCs undergoing chondrogenesis demonstrated an inverse effect, whereby there was decreased pellet size and GAG deposition, whilst there was an upregulation in hypertrophy genes. Thus, this pathway contributes to the control of hypertrophy during chondrogenesis and has been studied further [122].

The PI3K/Akt pathway was specifically investigated in MSC chondrogeneis to understand whether it is involved in the suppression of hypertrophy under physioxia [93]. A downregulation in COL10A1 and RUNX2 gene expression and reduced collagen X staining was observed for physioxia MSC chondrogenic pellets. They also describe an increase in the percentage of apoptotic cells (active caspase-3 and -8) within chondrogenic pellets under hyperoxia compared with physioxia. Western blot analysis confirmed that Akt was phosphorylated in chondrogenic pellets under physioxia. Use of the PI3K inhibitor (wortmannin) in physioxia chondrogenic pellets showed that blocking downstream Akt phosphorylation resulted in a downregulation in chondrogenic gene expression (SOX9, COL2A1, $A C A N$ ) and an upregulation in RUNX2 and COL10A1 gene expression. These data were supported by immunohistochemical staining whereby there was increased collagen $X$ and reduced GAG and collagen II staining in wortmannin treated pellets. Furthermore, there was a greater percentage of apoptotic cells (active caspase- 3 and caspase-8) within physioxia chondrogenic pellets in the presence of the inhibitor.

One of the downstream targets of the PI3K/Akt pathway is the Forkhead-box class O (FOXO) transcription factors that consist of four members, FOXO1, FOXO3, FOXO4 and FOXO6 [125,126]. FOXO1 and FOXO3 were expressed within normal articular cartilage, localised within the superficial zone and middle zone of the tissue. However, phosphorylation of FOXO1 and FOXO3 provokes nuclear export into the cytoplasm and subsequent degradation [123]. Previous studies have shown that FOXO1 and FOXO3 phosphorylation within cartilage leads to cell death and osteoarthritis due to the loss of autophagy genes that are known to protect chondrocytes from stress and are under the control of FOXO3 [127,128]. This was demonstrated in human cartilage, as OA cartilage had reduced expression for both FOXO1 and FOXO3 in the superficial zone compared to healthy cartilage, but had greater expression within the middle zone due chondrocyte clustering and phosphorylation which changed from the nucleus to the cytoplasm [123]. The importance of FOXO genes in articular cartilage homeostasis was further demonstrated, as FOXO1 and FOXO3 knockout mice developed more severe age-related OA compared with control mice, whilst the expression of autophagy genes was downregulated in triple knockout (FOXO1, -3 and -4) mice [124]. Furthermore, adenoviral expression of FOXO1 in human OA chondrocytes upregulated autophagy genes and countered the detrimental effects of IL-1 $\beta$. Thus, the FOXO genes are important contributors to cartilage homeostasis.

In physioxic MSC chondrogenesis, FOXO transcription factors with respect to cartilage hypertrophy have also been investigated [93]. FOXO1/FOXO3 was found to be expressed in physioxic chondrogenesis. However, inhibition of these transcription factors either via leptomycin B or 4-Hydroxynoneal replicated the response for physioxia chondrogenesis in the presence of wortmannin, whereby there was downregulation in chondrogenic gene expression, an upregulation in RUNX2 and COL10A1 gene expression with an increase in collagen $\mathrm{X}$ staining within these pellets. Furthermore, markers of apoptosis, active caspase- 3 and caspase-8, were found to increase in physioxia chondrogenic pellets in the presence of FOXO inhibitors.

Thus, the PI3K/Akt/FOXO pathway (Figure 3d) may be a critical pathway in chondrogenesis with respect to controlling the suppression of hypertrophy and cartilage homeostasis. This pathway also involves HIF-1 $\alpha$ and therefore the interactions between these transcription factors would require further investigation. Furthermore, how FOXO expression upregulates autophagy genes that help to protect against cartilage damage has not been determined, particularly with respect to MSC chondrogenesis 
in the presence of inflammatory cytokines (e.g., IL-1 $\beta$ ) and the mechanism countering its inhibition under physioxia.

\section{Summary}

In general, physioxia has an anabolic effect on MSC chondrogenesis whereby there is an upregulation in chondrogenesis genes (SOX9, COL2A1, ACAN) and a concomitant increased matrix deposition both within pellets and scaffolds when compared with hyperoxic conditions. In contrast to hyperoxic culture, physioxic chondrogenesis significantly downregulates the expression of hypertrophic genes, COL10A1 and MMP13, although subsequent staining suggests that physioxia does not completely suppress collagen $X$ production, particularly for donors whose cells produce a high amount of GAG (Tables 1 and 2). Implantation of physioxia preconditioned chondrogenic MSCs in nude mice and rabbit models replicated in vitro results in stable cartilage formation with reduced bone formation compared with hyperoxic MSC chondrogenic implants [81,82,92]. However, a similar study using a sheep model resulted in no differences in cartilaginous repair between physioxic and hyperoxic preconditioned chondrogenic implants [51]. More careful selection of MSC preparations may be required, as in spite of the downregulation of COL10A1 and MMP13 in high and low GAG donors, collagen $X$ staining was present in both donor types under physioxia, indicating only the suppression of hypertrophy [33]. To completely inhibit the hypertrophy in MSC chondrogenesis, additional environmental stimuli are required to stabilise the chondrogenic phenotype. Mechanical stimuli has been known to enhance cartilage matrix production in MSC chondrogenesis [129-131]. One form of stimulation is hydrostatic pressure that involves fluid pressurisation without cellular deformation $[132,133]$. Theoretical models have described that this form of loading can help maintain the chondrocyte phenotype and prevent hypertrophy $[134,135]$. However, there are contrary results in the literature; in some studies, hydrostatic pressure prevented MSC hypertrophy, but there are also publications indicating an upregulation in hypertrophic genes [136-142]. It would be of interest to investigate the combination of physioxia and hydrostatic pressure during MSC chondrogenesis.

MSCs and chondrocyte co-culture models have been tested to examine the effects on the two cell types $[67,143-145]$. It was hypothesized that the cross-talk between cell types could help to improve the cartilage tissues for in vivo implantation. It has been shown that direct MSC-chondrocyte co-cultures prevent cartilage hypertrophy [143]. It has been demonstrated that co-culturing MSCs and chondrocytes under physioxia helped to increase both cartilage formation and reduce hypertrophy compared to MSC monocultures under the same conditions [67]. Further investigations into MSC-chondrocyte co-culture systems under physioxia, possibly with loading, are warranted.

Physioxia helps counter the detrimental effects of inflammatory cytokines during in-vitro chondrogenesis [74]. However, the underlying mechanisms controlling the response have not been established. The HIFs have been the primary focus of the majority of studies on this phenomenon. It appears that HIF-1 $\alpha$ promotes the upregulation of chondrogenic matrix gene expression and HIF- $3 \alpha$ may help to stabilise the chondrogenic phenotype $[34,35,105,117]$. In contrast, some studies indicate that HIF- $2 \alpha$ upregulates both hypertrophic genes and matrix degradative enzymes $[107,108,110,111]$. However, there is also evidence that HIF- $2 \alpha$ is also involved in the chondrogenic anabolic response in both MSCs and chondrocytes under physioxia [26,42,72]. Further investigations are required to understand the function of HIF- $2 \alpha$ in the MSC chondrogenic response in physioxia, particularly in the regulation of inflammatory cytokines, as a means to using the HIF-related pathways to modulate the chondrocyte phenotype.

The PI3K/Akt/FOXO pathway (Figure 3d) is involved in preventing age-related OA; ectopic FOXO expression in OA chondrocytes in the presence of IL-1 $\beta$ upregulated genes associated with autophagy, thus countering the inhibitory effects of IL-1 $\beta$ [124]. This pathway has also been shown to be involved in reducing apoptosis and MSC chondrogenic hypertrophy in physioxia [93]. The reduction in apoptosis within chondrogenic pellets of MSCs may be related to the upregulation of autophagy genes that could also be a potential reason for the countering effect of physioxia on cytokine-inhibited 
chondrogenesis. Thus, further investigations are required into how the PI3K/Akt/FOXO pathway can contribute to alleviating cytokine-inhibited MSC chondrogenesis under physioxia, particularly with respect to autophagy genes and whether it can be manipulated to provide a fully protective effect. Another forkhead box transcription factor, FOXA, has also been implicated in the control of cartilage hypertrophy and subsequent endochondral ossification; therefore, further investigation into MSC chondrogenesis in physioxia could also consider its influence on the process [146].

\section{Future Directions and Outlook}

A STRING analysis was performed to investigate the possible interactions between the physioxia responsive pathway genes and chondrogenic genes (Figures 4 and 5) [147]. The plots describe the relationships between proteins based on experimental and theoretical results compiled and evaluated from various databases and predicts the probability of interactions between them (Figures 4 and 5). The analysis indicates a strong interaction or discrete clouds between the PI3K/AKT1/FOXO genes and the chondrogenic genes. In the first instance, PI3KCA is the central player with strong relationships between AKT and the different FOXO and FOXA genes evaluated. In terms of chondrogenic genes, $C O L 2 A 1$ and $A C A N$ are the central players. These discrete clouds have no direct interactions with a common gene between them (Figures 4 and 5). Potentially, one common link between the two clouds is TGF- $\beta$ receptor I, as the analysis shows a probable connection with PI3KCA. Therefore, one pathway for future investigation is the canonical and non-canonical TGF- $\beta$ pathways and observing whether the PI3K/Akt pathway is stimulated by this process [148]. Interestingly, the HIF genes are separated from the chondrogenic genes, with the only connection between HIF- $1 \alpha$ and SOX9, as described in this review [34]. The analysis also supports the experimental findings for the interaction between the PI3K/Akt/FOXO pathway and HIF-1 $\alpha$ (Figure 5) [121]. However, it is noteworthy that the analysis does not show a direct interaction between the HIFs and PI3K/Akt genes with respect to chondrogenic gene expression, whilst the probability that there is a relationship between these distinct clouds is low. Thus, the STRING evaluations demonstrate that further investigations are required in understanding the underlying mechanisms controlling physioxia MSC chondrogenesis.

Since the phenotype of MSC-derived chondrocytes is not optimal, alternative cell types are being considered for use in the treatment of early OA focal defects. Recent investigations in cartilage tissue engineering have begun to evaluate a cell population within the superficial layer of articular cartilage, termed articular cartilage progenitor cells (ACPs) [33,149-152]. ACPs are isolated via fibronectin adherence and can be clonally expanded to high population doublings without a loss in chondrogenic potential, unlike MSC populations that progressively lose their chondrogenicity at similar doublings $[149,151]$. Furthermore, clonal ACPs have reduced collagen $\mathrm{X}$ staining and markers for osteogenesis compared to bone marrow-derived MSCs [33,150]. Under physioxia, ACP clonal populations demonstrated a significant downregulation in COL10A1 and MMP13 relative to hyperoxia and also exhibited no collagen $X$ staining and protein expression in all ACP clones. In contrast, hyperoxic ACPs showed a clonal variability in collagen $X$ staining, whereby there was either no or abundant collagen $X$ staining, depending upon the clone [33]. Thus, ACPs are an alternative and potentially optimal cell source for the treatment of early $\mathrm{OA}$ focal defects, and physioxic preconditioning helps stabilise the chondrocyte phenotype.

In summary, culturing MSCs at physioxia increases proliferation and induces a greater anabolic response during chondrogenesis. Furthermore, physioxia supresses hypertrophy as judged by the downregulation in COL1OA1 and MMP13 expression, although it does not completely inhibit the process. Whether physioxic preconditioning provides beneficial effects upon implantation in vivo is not yet established. The underlying mechanisms controlling the physioxic response remain to be elucidated and may offer new targets for therapies if novel pathways are identified. 


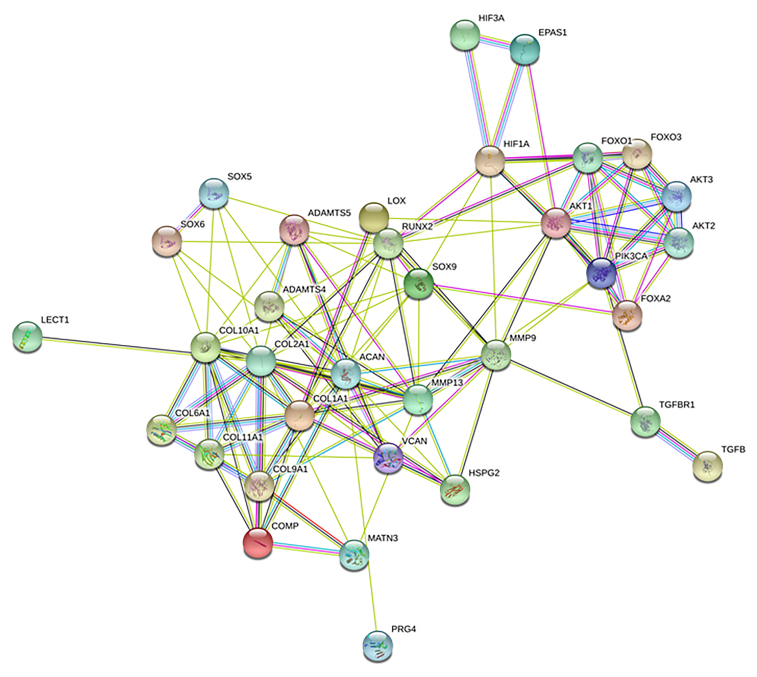

LEGEND
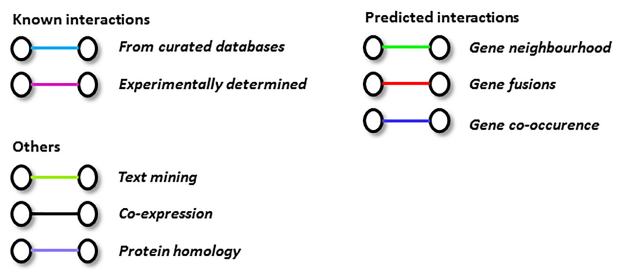

Figure 4. STRING database analysis based upon genes and proteins under the influence of physioxia and chondrogenesis, which describes the interactions based on the database analysis between proteins.

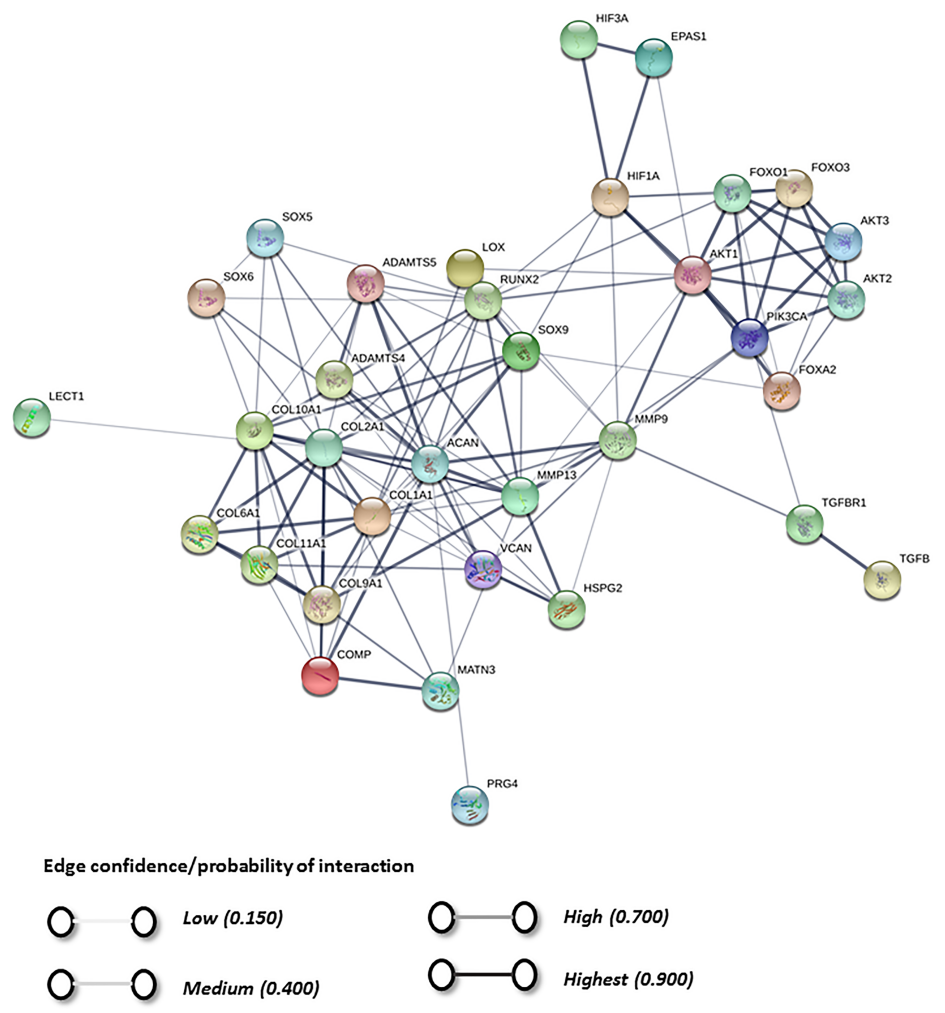

Figure 5. STRING database analysis based upon genes and proteins under the influence of physioxia and chondrogenesis, which describes the probability of interactions between proteins. 
Author Contributions: G.P. reviewed the literature and wrote the manuscript; B.J., J.Z., D.D., P.A. reviewed and edited the manuscript.

Funding: This work was supported by the Deutsche Forschungsgemeinschaft (DFG)/German Research Foundation Research network (FOR2407/1): Exploring cartilage and subchondral bone degeneration and regeneration in Osteoarthritis (ExCarBon) (SP7: Preconditioning of mesenchymal stem cells with mechanobiological load and hypoxia for joint regeneration in moderate osteoarthritis).

Conflicts of Interest: The authors declare no conflict of interest.

\section{References}

1. Sophia Fox, A.J.; Bedi, A.; Rodeo, S.A. The basic science of articular cartilage: Structure, composition, and function. Sports Health 2009, 1, 461-468. [CrossRef] [PubMed]

2. Buckwalter, J.A.; Mankin, H.J.; Grodzinsky, A.J. Articular cartilage and osteoarthritis. Instr. Course Lect. 2005, 54, 465-480. [PubMed]

3. Goldring, M.B. Osteoarthritis and cartilage: The role of cytokines. Curr. Rheumatol. Rep. 2000, 2, 459-465. [CrossRef] [PubMed]

4. Goldring, M.B.; Otero, M.; Plumb, D.A.; Dragomir, C.; Favero, M.; El Hachem, K.; Hashimoto, K.; Roach, H.I.; Olivotto, E.; Borzi, R.M.; et al. Roles of inflammatory and anabolic cytokines in cartilage metabolism: Signals and multiple effectors converge upon MMP-13 regulation in osteoarthritis. Eur. Cell Mater. 2011, 21, 202-220. [CrossRef] [PubMed]

5. Angele, P.; Fritz, J.; Albrecht, D.; Koh, J.; Zellner, J. Defect type, localization and marker gene expression determines early adverse events of matrix-associated autologous chondrocyte implantation. Injury 2015, 46 (Suppl. 4), S2-S9. [CrossRef]

6. Niemeyer, P.; Schweigler, K.; Grotejohann, B.; Maurer, J.; Angele, P.; Aurich, M.; Becher, C.; Fay, J.; Feil, R.; Fickert, S.; et al. The German Cartilage Registry (KnorpelRegister DGOU) for evaluation of surgical treatment for cartilage defects: Experience after six months including first demographic data. Z. Orthop. Unfall. 2015, 153, 67-74. [CrossRef] [PubMed]

7. Madry, H.; Kon, E.; Condello, V.; Peretti, G.M.; Steinwachs, M.; Seil, R.; Berruto, M.; Engebretsen, L.; Filardo, G.; Angele, P. Early osteoarthritis of the knee. Knee Surg. Sports Traumatol. Arthrosc. 2016, 24, 1753-1762. [CrossRef]

8. Luyten, F.P.; Denti, M.; Filardo, G.; Kon, E.; Engebretsen, L. Definition and classification of early osteoarthritis of the knee. Knee Surg. Sports Traumatol. Arthrosc. 2012, 20, 401-406. [CrossRef]

9. Madry, H.; Luyten, F.P.; Facchini, A. Biological aspects of early osteoarthritis. Knee Surg. Sports Traumatol. Arthrosc. 2012, 20, 407-422. [CrossRef]

10. McNulty, A.L.; Rothfusz, N.E.; Leddy, H.A.; Guilak, F. Synovial fluid concentrations and relative potency of interleukin-1 alpha and beta in cartilage and meniscus degradation. J. Orthop. Res. 2013, 31, 1039-1045. [CrossRef]

11. Brittberg, M.; Lindahl, A.; Nilsson, A.; Ohlsson, C.; Isaksson, O.; Peterson, L. Treatment of deep cartilage defects in the knee with autologous chondrocyte transplantation. N. Engl. J. Med. 1994, 331, 889-895. [CrossRef] [PubMed]

12. Niemeyer, P.; Andereya, S.; Angele, P.; Ateschrang, A.; Aurich, M.; Baumann, M.; Behrens, P.; Bosch, U.; Erggelet, C.; Fickert, S.; et al. Autologous chondrocyte implantation (ACI) for cartilage defects of the knee: A guideline by the working group "Tissue Regeneration" of the German Society of Orthopaedic Surgery and Traumatology (DGOU). Z. Orthop. Unfall. 2013, 151, 38-47. [CrossRef]

13. Pittenger, M.F.; Mackay, A.M.; Beck, S.C.; Jaiswal, R.K.; Douglas, R.; Mosca, J.D.; Moorman, M.A.; Simonetti, D.W.; Craig, S.; Marshak, D.R. Multilineage potential of adult human mesenchymal stem cells. Science 1999, 284, 143-147. [CrossRef] [PubMed]

14. Caplan, A.I. Mesenchymal stem cells. J. Orthop. Res. 1991, 9, 641-650. [CrossRef]

15. Gimble, J.; Guilak, F. Adipose-derived adult stem cells: Isolation, characterization, and differentiation potential. Cytotherapy 2003, 5, 362-369. [CrossRef]

16. Sakaguchi, Y.; Sekiya, I.; Yagishita, K.; Muneta, T. Comparison of human stem cells derived from various mesenchymal tissues: Superiority of synovium as a cell source. Arthritis Rheumatol. 2005, 52, 2521-2529. [CrossRef] [PubMed] 
17. Johnstone, B.; Hering, T.M.; Caplan, A.I.; Goldberg, V.M.; Yoo, J.U. In vitro chondrogenesis of bone marrow-derived mesenchymal progenitor cells. Exp. Cell Res. 1998, 238, 265-272. [CrossRef]

18. Yoo, J.U.; Barthel, T.S.; Nishimura, K.; Solchaga, L.; Caplan, A.I.; Goldberg, V.M.; Johnstone, B. The chondrogenic potential of human bone-marrow-derived mesenchymal progenitor cells. J. Bone Jt. Surg. Am. 1998, 80, 1745-1757. [CrossRef]

19. Pelttari, K.; Winter, A.; Steck, E.; Goetzke, K.; Hennig, T.; Ochs, B.G.; Aigner, T.; Richter, W. Premature induction of hypertrophy during in vitro chondrogenesis of human mesenchymal stem cells correlates with calcification and vascular invasion after ectopic transplantation in SCID mice. Arthritis Rheumatol. 2006, 54, 3254-3266. [CrossRef]

20. Lafont, J.E. Lack of oxygen in articular cartilage: Consequences for chondrocyte biology. Int. J. Exp. Pathol. 2010, 91, 99-106. [CrossRef]

21. Brighton, C.T.; Heppenstall, R.B. Oxygen tension in zones of the epiphyseal plate, the metaphysis and diaphysis. An in vitro and in vivo study in rats and rabbits. J. Bone Jt. Surg. Am. 1971, 53, 719-728. [CrossRef]

22. Lund-Olesen, K. Oxygen tension in synovial fluids. Arthritis Rheumatol. 1970, 13, 769-776. [CrossRef]

23. Grant, J.L.; Smith, B. Bone marrow gas tensions, bone marrow blood flow, and erythropoiesis in man. Ann. Intern. Med. 1963, 58, 801-809. [CrossRef]

24. Zhou, S.; Cui, Z.; Urban, J.P. Factors influencing the oxygen concentration gradient from the synovial surface of articular cartilage to the cartilage-bone interface: A modeling study. Arthritis Rheumatol. 2004, 50, 3915-3924. [CrossRef]

25. Lafont, J.E.; Talma, S.; Hopfgarten, C.; Murphy, C.L. Hypoxia promotes the differentiated human articular chondrocyte phenotype through SOX9-dependent and -independent pathways. J. Biol. Chem. 2008, 283, 4778-4786. [CrossRef] [PubMed]

26. Lafont, J.E.; Talma, S.; Murphy, C.L. Hypoxia-inducible factor $2 \alpha$ is essential for hypoxic induction of the human articular chondrocyte phenotype. Arthritis Rheumatol. 2007, 56, 3297-3306. [CrossRef] [PubMed]

27. Murphy, C.L.; Sambanis, A. Effect of oxygen tension on chondrocyte extracellular matrix accumulation. Connect. Tissue Res. 2001, 42, 87-96. [CrossRef]

28. Murphy, C.L.; Sambanis, A. Effect of oxygen tension and alginate encapsulation on restoration of the differentiated phenotype of passaged chondrocytes. Tissue Eng. 2001, 7, 791-803. [CrossRef] [PubMed]

29. Thoms, B.L.; Dudek, K.A.; Lafont, J.E.; Murphy, C.L. Hypoxia promotes the production and inhibits the destruction of human articular cartilage. Arthritis Rheumatol. 2013, 65, 1302-1312. [CrossRef] [PubMed]

30. Strobel, S.; Loparic, M.; Wendt, D.; Schenk, A.D.; Candrian, C.; Lindberg, R.L.; Moldovan, F.; Barbero, A.; Martin, I. Anabolic and catabolic responses of human articular chondrocytes to varying oxygen percentages. Arthritis Res. Ther. 2010, 12, R34. [CrossRef]

31. Markway, B.D.; Cho, H.; Johnstone, B. Hypoxia promotes redifferentiation and suppresses markers of hypertrophy and degeneration in both healthy and osteoarthritic chondrocytes. Arthritis Res. Ther. 2013, 15, R92. [CrossRef] [PubMed]

32. Mennan, C.; Garcia, J.; McCarthy, H.; Owen, S.; Perry, J.; Wright, K.; Banerjee, R.; Richardson, J.B.; Roberts, S. Human Articular Chondrocytes Retain Their Phenotype in Sustained Hypoxia While Normoxia Promotes Their Immunomodulatory Potential. Cartilage 2018, 1947603518769714. [CrossRef] [PubMed]

33. Anderson, D.E.; Markway, B.D.; Bond, D.; McCarthy, H.E.; Johnstone, B. Responses to altered oxygen tension are distinct between human stem cells of high and low chondrogenic capacity. Stem Cell Res. Ther. 2016, 7, 154. [CrossRef] [PubMed]

34. Schipani, E. Hypoxia and HIF-1alpha in chondrogenesis. Ann. N. Y. Acad. Sci. 2006, 1068, 66-73. [CrossRef]

35. Schipani, E.; Ryan, H.E.; Didrickson, S.; Kobayashi, T.; Knight, M.; Johnson, R.S. Hypoxia in cartilage: HIF-1alpha is essential for chondrocyte growth arrest and survival. Genes Dev. 2001, 15, 2865-2876. [CrossRef]

36. Taheem, D.K.; Foyt, D.A.; Loaiza, S.; Ferreira, S.A.; Ilic, D.; Auner, H.W.; Grigoriadis, A.E.; Jell, G.; Gentleman, E. Differential Regulation of Human Bone Marrow Mesenchymal Stromal Cell Chondrogenesis by Hypoxia Inducible Factor-1alpha Hydroxylase Inhibitors. Stem Cells 2018, 36, 1380-1392. [CrossRef]

37. Appelhoff, R.J.; Tian, Y.M.; Raval, R.R.; Turley, H.; Harris, A.L.; Pugh, C.W.; Ratcliffe, P.J.; Gleadle, J.M. Differential function of the prolyl hydroxylases PHD1, PHD2, and PHD3 in the regulation of hypoxia-inducible factor. J. Biol. Chem. 2004, 279, 38458-38465. [CrossRef] 
38. Tian, Y.M.; Yeoh, K.K.; Lee, M.K.; Eriksson, T.; Kessler, B.M.; Kramer, H.B.; Edelmann, M.J.; Willam, C.; Pugh, C.W.; Schofield, C.J.; et al. Differential sensitivity of hypoxia inducible factor hydroxylation sites to hypoxia and hydroxylase inhibitors. J. Biol. Chem. 2011, 286, 13041-13051. [CrossRef] [PubMed]

39. Littmann, E.; Autefage, H.; Solanki, A.K.; Kallepitis, C.; Jones, J.R.; Alini, M.; Peroglio, M.; Stevens, M.M. Cobalt-containing bioactive glasses reduce human mesenchymal stem cell chondrogenic differentiation despite HIF-1 $\alpha$ stabilisation. J. Eur. Ceram. Soc. 2018, 38, 877-886. [CrossRef]

40. Teti, G.; Focaroli, S.; Salvatore, V.; Mazzotti, E.; Ingra, L.; Mazzotti, A.; Falconi, M. The Hypoxia-Mimetic Agent Cobalt Chloride Differently Affects Human Mesenchymal Stem Cells in Their Chondrogenic Potential. Stem Cells Int. 2018, 2018, 3237253. [CrossRef]

41. Krinner, A.; Zscharnack, M.; Bader, A.; Drasdo, D.; Galle, J. Impact of oxygen environment on mesenchymal stem cell expansion and chondrogenic differentiation. Cell Prolif. 2009, 42, 471-484. [CrossRef] [PubMed]

42. Adesida, A.B.; Mulet-Sierra, A.; Jomha, N.M. Hypoxia mediated isolation and expansion enhances the chondrogenic capacity of bone marrow mesenchymal stromal cells. Stem Cell Res. Ther. 2012, 3, 9. [CrossRef] [PubMed]

43. Bornes, T.D.; Jomha, N.M.; Mulet-Sierra, A.; Adesida, A.B. Hypoxic culture of bone marrow-derived mesenchymal stromal stem cells differentially enhances in vitro chondrogenesis within cell-seeded collagen and hyaluronic acid porous scaffolds. Stem Cell Res. Ther. 2015, 6, 84. [CrossRef]

44. Boyette, L.B.; Creasey, O.A.; Guzik, L.; Lozito, T.; Tuan, R.S. Human bone marrow-derived mesenchymal stem cells display enhanced clonogenicity but impaired differentiation with hypoxic preconditioning. Stem Cells Transl. Med. 2014, 3, 241-254. [CrossRef]

45. Sheehy, E.J.; Buckley, C.T.; Kelly, D.J. Oxygen tension regulates the osteogenic, chondrogenic and endochondral phenotype of bone marrow derived mesenchymal stem cells. Biochem. Biophys. Res. Commun. 2012, 417, 305-310. [CrossRef] [PubMed]

46. Weijers, E.M.; Van Den Broek, L.J.; Waaijman, T.; Van Hinsbergh, V.W.; Gibbs, S.; Koolwijk, P. The influence of hypoxia and fibrinogen variants on the expansion and differentiation of adipose tissue-derived mesenchymal stem cells. Tissue Eng. Part A 2011, 17, 2675-2685. [CrossRef]

47. Bae, H.C.; Park, H.J.; Wang, S.Y.; Yang, H.R.; Lee, M.C.; Han, H.S. Hypoxic condition enhances chondrogenesis in synovium-derived mesenchymal stem cells. Biomater. Res. 2018, 22, 28. [CrossRef]

48. Xu, Y.; Malladi, P.; Chiou, M.; Bekerman, E.; Giaccia, A.J.; Longaker, M.T. In vitro expansion of adipose-derived adult stromal cells in hypoxia enhances early chondrogenesis. Tissue Eng. 2007, 13, 2981-2993. [CrossRef]

49. O'HEireamhoin, S.; Buckley, C.T.; Jones, E.; McGonagle, D.; Mulhall, K.J.; Kelly, D.J. Recapitulating aspects of the oxygen and substrate environment of the damaged joint milieu for stem cell-based cartilage tissue engineering. Tissue Eng. Part C Methods 2013, 19, 117-127. [CrossRef]

50. Kalpakci, K.N.; Brown, W.E.; Hu, J.C.; Athanasiou, K.A. Cartilage tissue engineering using dermis isolated adult stem cells: The use of hypoxia during expansion versus chondrogenic differentiation. PLOS ONE 2014, 9, e98570. [CrossRef]

51. Bornes, T.D.; Adesida, A.B.; Jomha, N.M. Articular Cartilage Repair with Mesenchymal Stem Cells After Chondrogenic Priming: A Pilot Study. Tissue Eng. Part A 2018, 24, 761-774. [CrossRef] [PubMed]

52. Yasui, Y.; Chijimatsu, R.; Hart, D.A.; Koizumi, K.; Sugita, N.; Shimomura, K.; Myoui, A.; Yoshikawa, H.; Nakamura, N. Preparation of Scaffold-Free Tissue-Engineered Constructs Derived from Human Synovial Mesenchymal Stem Cells Under Low Oxygen Tension Enhances Their Chondrogenic Differentiation Capacity. Tissue Eng. Part A 2016, 22, 490-500. [CrossRef] [PubMed]

53. Ohara, T.; Muneta, T.; Nakagawa, Y.; Matsukura, Y.; Ichinose, S.; Koga, H.; Tsuji, K.; Sekiya, I. <Original Article>Hypoxia enhances proliferation through increase of colony formation rate with chondrogenic potential in primary synovial mesenchymal stem cells. J. Med. Dent. Sci. 2016, 63, 61-70. [CrossRef] [PubMed]

54. Pattappa, G.; Thorpe, S.D.; Jegard, N.C.; Heywood, H.K.; de Bruijn, J.D.; Lee, D.A. Continuous and uninterrupted oxygen tension influences the colony formation and oxidative metabolism of human mesenchymal stem cells. Tissue Eng. Part C Methods 2013, 19, 68-79. [CrossRef] [PubMed]

55. Li, J.; Pei, M. Optimization of an in vitro three-dimensional microenvironment to reprogram synovium-derived stem cells for cartilage tissue engineering. Tissue Eng. Part A 2011, 17, 703-712. [CrossRef] [PubMed] 
56. Wang, G.; Woods, A.; Sabari, S.; Pagnotta, L.; Stanton, L.A.; Beier, F. RhoA/ROCK signaling suppresses hypertrophic chondrocyte differentiation. J. Biol. Chem. 2004, 279, 13205-13214. [CrossRef] [PubMed]

57. Pattappa, G.; Heywood, H.K.; de Bruijn, J.D.; Lee, D.A. The metabolism of human mesenchymal stem cells during proliferation and differentiation. J. Cell. Physiol. 2011, 226, 2562-2570. [CrossRef]

58. Moussavi-Harami, F.; Duwayri, Y.; Martin, J.A.; Moussavi-Harami, F.; Buckwalter, J.A. Oxygen effects on senescence in chondrocytes and mesenchymal stem cells: Consequences for tissue engineering. Iowa Orthop. J. 2004, 24, 15-20. [PubMed]

59. D'Ippolito, G.; Diabira, S.; Howard, G.A.; Roos, B.A.; Schiller, P.C. Low oxygen tension inhibits osteogenic differentiation and enhances stemness of human MIAMI cells. Bone 2006, 39, 513-522. [CrossRef]

60. Rios, C.; D'Ippolito, G.; Curtis, K.M.; Delcroix, G.J.; Gomez, L.A.; El Hokayem, J.; Rieger, M.; Parrondo, R.; de Las Pozas, A.; Perez-Stable, C.; et al. Low Oxygen Modulates Multiple Signaling Pathways, Increasing Self-Renewal, While Decreasing Differentiation, Senescence, and Apoptosis in Stromal MIAMI Cells. Stem Cells Dev. 2016, 25, 848-860. [CrossRef]

61. Robins, J.C.; Akeno, N.; Mukherjee, A.; Dalal, R.R.; Aronow, B.J.; Koopman, P.; Clemens, T.L. Hypoxia induces chondrocyte-specific gene expression in mesenchymal cells in association with transcriptional activation of Sox9. Bone 2005, 37, 313-322. [CrossRef] [PubMed]

62. Muller, J.; Benz, K.; Ahlers, M.; Gaissmaier, C.; Mollenhauer, J. Hypoxic conditions during expansion culture prime human mesenchymal stromal precursor cells for chondrogenic differentiation in three-dimensional cultures. Cell Transplant. 2011, 20, 1589-1602. [CrossRef]

63. Pilgaard, L.; Lund, P.; Duroux, M.; Lockstone, H.; Taylor, J.; Emmersen, J.; Fink, T.; Ragoussis, J.; Zachar, V. Transcriptional signature of human adipose tissue-derived stem cells (hASCs) preconditioned for chondrogenesis in hypoxic conditions. Exp. Cell Res. 2009, 315, 1937-1952. [CrossRef] [PubMed]

64. Merceron, C.; Vinatier, C.; Portron, S.; Masson, M.; Amiaud, J.; Guigand, L.; Cherel, Y.; Weiss, P.; Guicheux, J. Differential effects of hypoxia on osteochondrogenic potential of human adipose-derived stem cells. Am. J. Physiol. Cell Physiol. 2010, 298, C355-C364. [CrossRef] [PubMed]

65. Betre, H.; Ong, S.R.; Guilak, F.; Chilkoti, A.; Fermor, B.; Setton, L.A. Chondrocytic differentiation of human adipose-derived adult stem cells in elastin-like polypeptide. Biomaterials 2006, 27, 91-99. [CrossRef]

66. Malladi, P.; Xu, Y.; Chiou, M.; Giaccia, A.J.; Longaker, M.T. Effect of reduced oxygen tension on chondrogenesis and osteogenesis in adipose-derived mesenchymal cells. Am. J. Physiol. Cell Physiol. 2006, 290, C1139-C1146. [CrossRef]

67. Meretoja, V.V.; Dahlin, R.L.; Wright, S.; Kasper, F.K.; Mikos, A.G. The effect of hypoxia on the chondrogenic differentiation of co-cultured articular chondrocytes and mesenchymal stem cells in scaffolds. Biomaterials 2013, 34, 4266-4273. [CrossRef]

68. Desance, M.; Contentin, R.; Bertoni, L.; Gomez-Leduc, T.; Branly, T.; Jacquet, S.; Betsch, J.M.; Batho, A.; Legendre, F.; Audigie, F.; et al. Chondrogenic Differentiation of Defined Equine Mesenchymal Stem Cells Derived from Umbilical Cord Blood for Use in Cartilage Repair Therapy. Int. J. Mol. Sci. 2018, $19,537$. [CrossRef]

69. Gomez-Leduc, T.; Desance, M.; Hervieu, M.; Legendre, F.; Ollitrault, D.; de Vienne, C.; Herlicoviez, M.; Galera, P.; Demoor, M. Hypoxia Is a Critical Parameter for Chondrogenic Differentiation of Human Umbilical Cord Blood Mesenchymal Stem Cells in Type I/III Collagen Sponges. Int. J. Mol. Sci. 2017, 18, 1933. [CrossRef]

70. Munir, S.; Foldager, C.B.; Lind, M.; Zachar, V.; Soballe, K.; Koch, T.G. Hypoxia enhances chondrogenic differentiation of human adipose tissue-derived stromal cells in scaffold-free and scaffold systems. Cell Tissue Res. 2014, 355, 89-102. [CrossRef]

71. Wang, D.W.; Fermor, B.; Gimble, J.M.; Awad, H.A.; Guilak, F. Influence of oxygen on the proliferation and metabolism of adipose derived adult stem cells. J. Cell. Physiol. 2005, 204, 184-191. [CrossRef] [PubMed]

72. Khan, W.S.; Adesida, A.B.; Hardingham, T.E. Hypoxic conditions increase hypoxia-inducible transcription factor $2 \alpha$ and enhance chondrogenesis in stem cells from the infrapatellar fat pad of osteoarthritis patients. Arthritis Res. Ther. 2007, 9, R55. [CrossRef] [PubMed]

73. Malladi, P.; Xu, Y.; Chiou, M.; Giaccia, A.J.; Longaker, M.T. Hypoxia inducible factor-1alpha deficiency affects chondrogenesis of adipose-derived adult stromal cells. Tissue Eng. 2007, 13, 1159-1171. [CrossRef] [PubMed]

74. Felka, T.; Schafer, R.; Schewe, B.; Benz, K.; Aicher, W.K. Hypoxia reduces the inhibitory effect of IL-1 $\beta$ on chondrogenic differentiation of FCS-free expanded MSC. Osteoarthr. Cartil. 2009, 17, 1368-1376. [CrossRef] 
75. Baumgartner, L.; Arnhold, S.; Brixius, K.; Addicks, K.; Bloch, W. Human mesenchymal stem cells: Influence of oxygen pressure on proliferation and chondrogenic differentiation in fibrin glue in vitro. J. Biomed. Mater. Res. A 2010, 93, 930-940. [CrossRef] [PubMed]

76. Buckley, C.T.; Vinardell, T.; Kelly, D.J. Oxygen tension differentially regulates the functional properties of cartilaginous tissues engineered from infrapatellar fat pad derived MSCs and articular chondrocytes. Osteoarthr. Cartil. 2010, 18, 1345-1354. [CrossRef]

77. Khan, W.S.; Adesida, A.B.; Tew, S.R.; Lowe, E.T.; Hardingham, T.E. Bone marrow-derived mesenchymal stem cells express the pericyte marker 3G5 in culture and show enhanced chondrogenesis in hypoxic conditions. J. Orthop. Res. 2010, 28, 834-840. [CrossRef]

78. Meyer, E.G.; Buckley, C.T.; Thorpe, S.D.; Kelly, D.J. Low oxygen tension is a more potent promoter of chondrogenic differentiation than dynamic compression. J. Biomech. 2010, 43, 2516-2523. [CrossRef]

79. Stoyanov, J.V.; Gantenbein-Ritter, B.; Bertolo, A.; Aebli, N.; Baur, M.; Alini, M.; Grad, S. Role of hypoxia and growth and differentiation factor- 5 on differentiation of human mesenchymal stem cells towards intervertebral nucleus pulposus-like cells. Eur. Cell Mater. 2011, 21, 533-547. [CrossRef]

80. Gawlitta, D.; van Rijen, M.H.; Schrijver, E.J.; Alblas, J.; Dhert, W.J. Hypoxia impedes hypertrophic chondrogenesis of human multipotent stromal cells. Tissue Eng. Part A 2012, 18, 1957-1966. [CrossRef]

81. Portron, S.; Merceron, C.; Gauthier, O.; Lesoeur, J.; Sourice, S.; Masson, M.; Fellah, B.H.; Geffroy, O.; Lallemand, E.; Weiss, P.; et al. Effects of in vitro low oxygen tension preconditioning of adipose stromal cells on their in vivo chondrogenic potential: Application in cartilage tissue repair. PLoS ONE 2013, 8, e62368. [CrossRef] [PubMed]

82. Leijten, J.; Georgi, N.; Moreira Teixeira, L.; van Blitterswijk, C.A.; Post, J.N.; Karperien, M. Metabolic programming of mesenchymal stromal cells by oxygen tension directs chondrogenic cell fate. Proc. Natl. Acad. Sci. USA 2014, 111, 13954-13959. [CrossRef] [PubMed]

83. Zhu, M.; Feng, Q.; Bian, L. Differential effect of hypoxia on human mesenchymal stem cell chondrogenesis and hypertrophy in hyaluronic acid hydrogels. Acta Biomater. 2014, 10, 1333-1340. [CrossRef]

84. Portron, S.; Hivernaud, V.; Merceron, C.; Lesoeur, J.; Masson, M.; Gauthier, O.; Vinatier, C.; Beck, L.; Guicheux, J. Inverse regulation of early and late chondrogenic differentiation by oxygen tension provides cues for stem cell-based cartilage tissue engineering. Cell. Physiol. Biochem. 2015, 35, 841-857. [CrossRef]

85. Markway, B.D.; Cho, H.; Anderson, D.E.; Holden, P.; Ravi, V.; Little, C.B.; Johnstone, B. Reoxygenation enhances tumour necrosis factor alpha-induced degradation of the extracellular matrix produced by chondrogenic cells. Eur. Cell Mater. 2016, 31, 425-439. [CrossRef] [PubMed]

86. Galeano-Garces, C.; Camilleri, E.T.; Riester, S.M.; Dudakovic, A.; Larson, D.R.; Qu, W.; Smith, J.; Dietz, A.B.; Im, H.J.; Krych, A.J.; et al. Molecular Validation of Chondrogenic Differentiation and Hypoxia Responsiveness of Platelet-Lysate Expanded Adipose Tissue-Derived Human Mesenchymal Stromal Cells. Cartilage 2017, 8, 283-299. [CrossRef] [PubMed]

87. Legendre, F.; Ollitrault, D.; Gomez-Leduc, T.; Bouyoucef, M.; Hervieu, M.; Gruchy, N.; Mallein-Gerin, F.; Leclercq, S.; Demoor, M.; Galera, P. Enhanced chondrogenesis of bone marrow-derived stem cells by using a combinatory cell therapy strategy with BMP-2/TGF-beta1, hypoxia, and COL1A1/HtrA1 siRNAs. Sci. Rep. 2017, 7, 3406. [CrossRef]

88. Rodenas-Rochina, J.; Kelly, D.J.; Gomez Ribelles, J.L.; Lebourg, M. Influence of oxygen levels on chondrogenesis of porcine mesenchymal stem cells cultured in polycaprolactone scaffolds. J. Biomed. Mater. Res. A 2017, 105, 1684-1691. [CrossRef]

89. Martin-Rendon, E.; Hale, S.J.; Ryan, D.; Baban, D.; Forde, S.P.; Roubelakis, M.; Sweeney, D.; Moukayed, M.; Harris, A.L.; Davies, K.; et al. Transcriptional profiling of human cord blood CD133 ${ }^{+}$and cultured bone marrow mesenchymal stem cells in response to hypoxia. Stem Cells 2007, 25, 1003-1012. [CrossRef] [PubMed]

90. Markway, B.D.; Tan, G.K.; Brooke, G.; Hudson, J.E.; Cooper-White, J.J.; Doran, M.R. Enhanced chondrogenic differentiation of human bone marrow-derived mesenchymal stem cells in low oxygen environment micropellet cultures. Cell Transplant. 2010, 19, 29-42. [CrossRef]

91. Ronziere, M.C.; Perrier, E.; Mallein-Gerin, F.; Freyria, A.M. Chondrogenic potential of bone marrow- and adipose tissue-derived adult human mesenchymal stem cells. Biomed. Mater. Eng. 2010, 20, 145-158. [CrossRef] [PubMed] 
92. Duval, E.; Bauge, C.; Andriamanalijaona, R.; Benateau, H.; Leclercq, S.; Dutoit, S.; Poulain, L.; Galera, P.; Boumediene, K. Molecular mechanism of hypoxia-induced chondrogenesis and its application in in vivo cartilage tissue engineering. Biomaterials 2012, 33, 6042-6051. [CrossRef]

93. Lee, H.H.; Chang, C.C.; Shieh, M.J.; Wang, J.P.; Chen, Y.T.; Young, T.H.; Hung, S.C. Hypoxia enhances chondrogenesis and prevents terminal differentiation through PI3K/Akt/FoxO dependent anti-apoptotic effect. Sci. Rep. 2013, 3, 2683. [CrossRef]

94. Ranera, B.; Remacha, A.R.; Alvarez-Arguedas, S.; Castiella, T.; Vazquez, F.J.; Romero, A.; Zaragoza, P.; Martin-Burriel, I.; Rodellar, C. Expansion under hypoxic conditions enhances the chondrogenic potential of equine bone marrow-derived mesenchymal stem cells. Vet. J. 2013, 195, 248-251. [CrossRef]

95. Henrionnet, C.; Liang, G.; Roeder, E.; Dossot, M.; Wang, H.; Magdalou, J.; Gillet, P.; Pinzano, A. Hypoxia for Mesenchymal Stem Cell Expansion and Differentiation: The Best Way for Enhancing TGFss-Induced Chondrogenesis and Preventing Calcifications in Alginate Beads. Tissue Eng. Part A 2017, 23, 913-922. [CrossRef] [PubMed]

96. Hudson, K.D.; Bonassar, L.J. Hypoxic Expansion of Human Mesenchymal Stem Cells Enhances Three-Dimensional Maturation of Tissue-Engineered Intervertebral Discs. Tissue Eng. Part A 2017, 23, 293-300. [CrossRef]

97. Lee, J.S.; Kim, S.K.; Jung, B.J.; Choi, S.B.; Choi, E.Y.; Kim, C.S. Enhancing proliferation and optimizing the culture condition for human bone marrow stromal cells using hypoxia and fibroblast growth factor-2. Stem Cell Res. 2018, 28, 87-95. [CrossRef]

98. Liu, Y.; Buckley, C.T.; Downey, R.; Mulhall, K.J.; Kelly, D.J. The role of environmental factors in regulating the development of cartilaginous grafts engineered using osteoarthritic human infrapatellar fat pad-derived stem cells. Tissue Eng. Part A 2012, 18, 1531-1541. [CrossRef]

99. Pattappa, G.S.R.; Hofmeister, I.; Seja, J.; Zellner, J.; Johnstone, B.; Docheva, D.; Angele, P. Physioxia has a beneficial effect on cartilage matrix production in interleukin- $1 \beta$ inhibited mesenchymal stem cell chondrogenesis. Stem Cells Int. 2018. in submit.

100. Giovannini, S.; Diaz-Romero, J.; Aigner, T.; Mainil-Varlet, P.; Nesic, D. Population doublings and percentage of S100-positive cells as predictors of in vitro chondrogenicity of expanded human articular chondrocytes. J. Cell. Physiol. 2010, 222, 411-420. [CrossRef]

101. Bauge, C.; Legendre, F.; Leclercq, S.; Elissalde, J.M.; Pujol, J.P.; Galera, P.; Boumediene, K. Interleukin-1 $\beta$ impairment of transforming growth factor $\beta 1$ signaling by down-regulation of transforming growth factor beta receptor type II and up-regulation of Smad7 in human articular chondrocytes. Arthritis Rheumatol. 2007, 56, 3020-3032. [CrossRef]

102. Bauge, C.; Attia, J.; Leclercq, S.; Pujol, J.P.; Galera, P.; Boumediene, K. Interleukin-1beta up-regulation of Smad7 via NF-kB activation in human chondrocytes. Arthritis Rheumatol. 2008, 58, 221-226. [CrossRef] [PubMed]

103. Bauge, C.; Beauchef, G.; Leclercq, S.; Kim, S.J.; Pujol, J.P.; Galera, P.; Boumediene, K. NFkB mediates IL-1 $\beta$-induced down-regulation of T $\beta$ RII through the modulation of Sp3 expression. J. Cell. Mol. Med. 2008, 12, 1754-1766. [CrossRef] [PubMed]

104. Pfander, D.; Cramer, T.; Swoboda, B. Hypoxia and HIF-1 $\alpha$ in osteoarthritis. Int. Orthop. 2005, $29,6-9$. [CrossRef] [PubMed]

105. Myllyharju, J.; Schipani, E. Extracellular matrix genes as hypoxia-inducible targets. Cell Tissue Res. 2010, 339, 19-29. [CrossRef]

106. Fernandez-Torres, J.; Zamudio-Cuevas, Y.; Martinez-Nava, G.A.; Lopez-Reyes, A.G. Hypoxia-Inducible Factors (HIFs) in the articular cartilage: A systematic review. Eur. Rev. Med. Pharmacol. Sci. 2017, 21, 2800-2810. [PubMed]

107. Yang, S.; Kim, J.; Ryu, J.H.; Oh, H.; Chun, C.H.; Kim, B.J.; Min, B.H.; Chun, J.S. Hypoxia-inducible factor-2 $\alpha$ is a catabolic regulator of osteoarthritic cartilage destruction. Nat. Med. 2010, 16, 687-693. [CrossRef] [PubMed]

108. Saito, T.; Kawaguchi, H. HIF-2 $\alpha$ as a possible therapeutic target of osteoarthritis. Osteoarthr. Cartil. 2010, 18, 1552-1556. [CrossRef]

109. Coimbra, I.B.; Jimenez, S.A.; Hawkins, D.F.; Piera-Velazquez, S.; Stokes, D.G. Hypoxia inducible factor- $1 \alpha$ expression in human normal and osteoarthritic chondrocytes. Osteoarthr. Cartil. 2004, 12, 336-345. [CrossRef] 
110. Saito, T.; Fukai, A.; Mabuchi, A.; Ikeda, T.; Yano, F.; Ohba, S.; Nishida, N.; Akune, T.; Yoshimura, N.; Nakagawa, T.; et al. Transcriptional regulation of endochondral ossification by HIF-2 $\alpha$ during skeletal growth and osteoarthritis development. Nat. Med. 2010, 16, 678-686. [CrossRef] [PubMed]

111. Ryu, J.H.; Yang, S.; Shin, Y.; Rhee, J.; Chun, C.H.; Chun, J.S. Interleukin-6 plays an essential role in hypoxia-inducible factor $2 \alpha$-induced experimental osteoarthritic cartilage destruction in mice. Arthritis Rheumatol. 2011, 63, 2732-2743. [CrossRef]

112. Araldi, E.; Khatri, R.; Giaccia, A.J.; Simon, M.C.; Schipani, E. Lack of HIF-2 $\alpha$ in limb bud mesenchyme causes a modest and transient delay of endochondral bone development. Nat. Med. 2011, 17, 25-26; author reply 27-29. [CrossRef] [PubMed]

113. Nakajima, M.; Shi, D.; Dai, J.; Tsezou, A.; Zheng, M.; Norman, P.E.; Chou, C.H.; Lee, M.T.; Hwang, J.Y.; Kim, D.H.; et al. A large-scale replication study for the association of rs17039192 in HIF-2 $\alpha$ with knee osteoarthritis. J. Orthop. Res. 2012, 30, 1244-1248. [CrossRef] [PubMed]

114. Murphy, C.L. HIF-2 $\alpha$-A mediator of osteoarthritis? Cell Res. 2010, 20, 977-979. [CrossRef] [PubMed]

115. Schrobback, K.; Klein, T.J.; Crawford, R.; Upton, Z.; Malda, J.; Leavesley, D.I. Effects of oxygen and culture system on in vitro propagation and redifferentiation of osteoarthritic human articular chondrocytes. Cell Tissue Res. 2012, 347, 649-663. [CrossRef] [PubMed]

116. Ruan, M.Z.; Erez, A.; Guse, K.; Dawson, B.; Bertin, T.; Chen, Y.; Jiang, M.M.; Yustein, J.; Gannon, F.; Lee, B.H. Proteoglycan 4 expression protects against the development of osteoarthritis. Sci. Transl. Med. 2013, 5, 176ra134. [CrossRef] [PubMed]

117. Markway, B.D.; Cho, H.; Zilberman-Rudenko, J.; Holden, P.; McAlinden, A.; Johnstone, B. Hypoxia-inducible factor 3- $\alpha$ expression is associated with the stable chondrocyte phenotype. J. Orthop. Res. 2015, 33, 1561-1570. [CrossRef]

118. Aghajanian, P.; Mohan, S. The art of building bone: Emerging role of chondrocyte-to-osteoblast transdifferentiation in endochondral ossification. Bone Res. 2018, 6, 19. [CrossRef]

119. Ono, N.; Ono, W.; Nagasawa, T.; Kronenberg, H.M. A subset of chondrogenic cells provides early mesenchymal progenitors in growing bones. Nat. Cell Biol. 2014, 16, 1157-1167. [CrossRef]

120. Pacifici, M.; Golden, E.B.; Oshima, O.; Shapiro, I.M.; Leboy, P.S.; Adams, S.L. Hypertrophic chondrocytes. The terminal stage of differentiation in the chondrogenic cell lineage? Ann. N. Y. Acad. Sci. 1990, 599, 45-57. [CrossRef]

121. Kita, K.; Kimura, T.; Nakamura, N.; Yoshikawa, H.; Nakano, T. PI3K/Akt signaling as a key regulatory pathway for chondrocyte terminal differentiation. Genes Cells 2008, 13, 839-850. [CrossRef]

122. Beier, F.; Loeser, R.F. Biology and pathology of Rho GTPase, PI-3 kinase-Akt, and MAP kinase signaling pathways in chondrocytes. J. Cell. Biochem. 2010, 110, 573-580. [CrossRef] [PubMed]

123. Akasaki, Y.; Hasegawa, A.; Saito, M.; Asahara, H.; Iwamoto, Y.; Lotz, M.K. Dysregulated FOXO transcription factors in articular cartilage in aging and osteoarthritis. Osteoarthr. Cartil. 2014, 22, 162-170. [CrossRef] [PubMed]

124. Matsuzaki, T.; Alvarez-Garcia, O.; Mokuda, S.; Nagira, K.; Olmer, M.; Gamini, R.; Miyata, K.; Akasaki, Y.; $\mathrm{Su}$, A.I.; Asahara, H.; et al. FoxO transcription factors modulate autophagy and proteoglycan 4 in cartilage homeostasis and osteoarthritis. Sci. Transl. Med. 2018, 10. [CrossRef]

125. Nakae, J.; Oki, M.; Cao, Y. The FoxO transcription factors and metabolic regulation. FEBS Lett. 2008, 582, 54-67. [CrossRef] [PubMed]

126. van der Horst, A.; Burgering, B.M. Stressing the role of FoxO proteins in lifespan and disease. Nat. Rev. Mol. Cell Biol. 2007, 8, 440-450. [CrossRef]

127. Carames, B.; Taniguchi, N.; Otsuki, S.; Blanco, F.J.; Lotz, M. Autophagy is a protective mechanism in normal cartilage, and its aging-related loss is linked with cell death and osteoarthritis. Arthritis Rheumatol. 2010, 62, 791-801. [CrossRef]

128. Lotz, M.K.; Carames, B. Autophagy and cartilage homeostasis mechanisms in joint health, aging and OA. Nat. Rev. Rheumatol. 2011, 7, 579-587. [CrossRef]

129. Anderson, D.E.; Johnstone, B. Dynamic Mechanical Compression of Chondrocytes for Tissue Engineering: A Critical Review. Front. Bioeng. Biotechnol. 2017, 5, 76. [CrossRef]

130. Huang, A.H.; Farrell, M.J.; Mauck, R.L. Mechanics and mechanobiology of mesenchymal stem cell-based engineered cartilage. J. Biomech. 2010, 43, 128-136. [CrossRef] 
131. O'Conor, C.J.; Case, N.; Guilak, F. Mechanical regulation of chondrogenesis. Stem Cell Res. Ther. $2013,4,61$. [CrossRef] [PubMed]

132. Soltz, M.A.; Ateshian, G.A. Interstitial fluid pressurization during confined compression cyclical loading of articular cartilage. Ann. Biomed. Eng. 2000, 28, 150-159. [CrossRef] [PubMed]

133. Soltz, M.A.; Ateshian, G.A. Experimental verification and theoretical prediction of cartilage interstitial fluid pressurization at an impermeable contact interface in confined compression. J. Biomech. 1998, 31, 927-934. [CrossRef]

134. Giorgi, M.; Carriero, A.; Shefelbine, S.J.; Nowlan, N.C. Mechanobiological simulations of prenatal joint morphogenesis. J. Biomech. 2014, 47, 989-995. [CrossRef] [PubMed]

135. Carter, D.R.; Wong, M. Modelling cartilage mechanobiology. Philos. Trans. R. Soc. Lond. B Biol. Sci. 2003, 358, 1461-1471. [CrossRef] [PubMed]

136. Saha, A.; Rolfe, R.; Carroll, S.; Kelly, D.J.; Murphy, P. Chondrogenesis of embryonic limb bud cells in micromass culture progresses rapidly to hypertrophy and is modulated by hydrostatic pressure. Cell Tissue Res. 2017, 368, 47-59. [CrossRef] [PubMed]

137. Vinardell, T.; Rolfe, R.A.; Buckley, C.T.; Meyer, E.G.; Ahearne, M.; Murphy, P.; Kelly, D.J. Hydrostatic pressure acts to stabilise a chondrogenic phenotype in porcine joint tissue derived stem cells. Eur. Cell Mater. 2012, 23, 121-132; discussion 133-134. [CrossRef] [PubMed]

138. Ogawa, R.; Mizuno, S.; Murphy, G.F.; Orgill, D.P. The effect of hydrostatic pressure on three-dimensional chondroinduction of human adipose-derived stem cells. Tissue Eng. Part A 2009, 15, 2937-2945. [CrossRef]

139. Ogawa, R.; Orgill, D.P.; Murphy, G.F.; Mizuno, S. Hydrostatic pressure-driven three-dimensional cartilage induction using human adipose-derived stem cells and collagen gels. Tissue Eng. Part A 2015, 21, 257-266. [CrossRef]

140. Li, J.; Zhao, Z.; Yang, J.; Liu, J.; Wang, J.; Li, X.; Liu, Y. p38 MAPK mediated in compressive stress-induced chondrogenesis of rat bone marrow MSCs in 3D alginate scaffolds. J. Cell. Physiol. 2009, 221, 609-617. [CrossRef]

141. Liu, Y.; Buckley, C.T.; Almeida, H.V.; Mulhall, K.J.; Kelly, D.J. Infrapatellar fat pad-derived stem cells maintain their chondrogenic capacity in disease and can be used to engineer cartilaginous grafts of clinically relevant dimensions. Tissue Eng. Part A 2014, 20, 3050-3062. [CrossRef] [PubMed]

142. Steward, A.J.; Thorpe, S.D.; Vinardell, T.; Buckley, C.T.; Wagner, D.R.; Kelly, D.J. Cell-matrix interactions regulate mesenchymal stem cell response to hydrostatic pressure. Acta Biomater. 2012, 8, 2153-2159. [CrossRef] [PubMed]

143. Cooke, M.E.; Allon, A.A.; Cheng, T.; Kuo, A.C.; Kim, H.T.; Vail, T.P.; Marcucio, R.S.; Schneider, R.A.; Lotz, J.C.; Alliston, T. Structured three-dimensional co-culture of mesenchymal stem cells with chondrocytes promotes chondrogenic differentiation without hypertrophy. Osteoarthr. Cartil. 2011, 19, 1210-1218. [CrossRef] [PubMed]

144. Acharya, C.; Adesida, A.; Zajac, P.; Mumme, M.; Riesle, J.; Martin, I.; Barbero, A. Enhanced chondrocyte proliferation and mesenchymal stromal cells chondrogenesis in coculture pellets mediate improved cartilage formation. J. Cell. Physiol. 2012, 227, 88-97. [CrossRef]

145. Wu, L.; Post, J.N.; Karperien, M. Engineering cartilage tissue by pellet coculture of chondrocytes and mesenchymal stromal cells. Methods Mol. Biol. 2015, 1226, 31-41. [CrossRef]

146. Ionescu, A.; Kozhemyakina, E.; Nicolae, C.; Kaestner, K.H.; Olsen, B.R.; Lassar, A.B. FoxA family members are crucial regulators of the hypertrophic chondrocyte differentiation program. Dev. Cell 2012, 22, 927-939. [CrossRef]

147. Szklarczyk, D.; Franceschini, A.; Wyder, S.; Forslund, K.; Heller, D.; Huerta-Cepas, J.; Simonovic, M.; Roth, A.; Santos, A.; Tsafou, K.P.; et al. STRING v10: Protein-protein interaction networks, integrated over the tree of life. Nucleic Acids Res. 2015, 43, D447-D452. [CrossRef]

148. Cleary, M.A.; van Osch, G.J.; Brama, P.A.; Hellingman, C.A.; Narcisi, R. FGF, TGF $\beta$ and Wnt crosstalk: Embryonic to in vitro cartilage development from mesenchymal stem cells. J. Tissue Eng. Regen. Med. 2015, 9, 332-342. [CrossRef]

149. Williams, R.; Khan, I.M.; Richardson, K.; Nelson, L.; McCarthy, H.E.; Analbelsi, T.; Singhrao, S.K.; Dowthwaite, G.P.; Jones, R.E.; Baird, D.M.; et al. Identification and clonal characterisation of a progenitor cell sub-population in normal human articular cartilage. PLoS ONE 2010, 5, e13246. [CrossRef] 
150. McCarthy, H.E.; Bara, J.J.; Brakspear, K.; Singhrao, S.K.; Archer, C.W. The comparison of equine articular cartilage progenitor cells and bone marrow-derived stromal cells as potential cell sources for cartilage repair in the horse. Vet. J. 2012, 192, 345-351. [CrossRef]

151. Nelson, L.; McCarthy, H.E.; Fairclough, J.; Williams, R.; Archer, C.W. Evidence of a Viable Pool of Stem Cells within Human Osteoarthritic Cartilage. Cartilage 2014, 5, 203-214. [CrossRef] [PubMed]

152. Dowthwaite, G.P.; Bishop, J.C.; Redman, S.N.; Khan, I.M.; Rooney, P.; Evans, D.J.; Haughton, L.; Bayram, Z.; Boyer, S.; Thomson, B.; et al. The surface of articular cartilage contains a progenitor cell population. J. Cell Sci. 2004, 117, 889-897. [CrossRef] [PubMed]

(C) 2019 by the authors. Licensee MDPI, Basel, Switzerland. This article is an open access article distributed under the terms and conditions of the Creative Commons Attribution (CC BY) license (http://creativecommons.org/licenses/by/4.0/). 